\title{
Financial Development, Sectoral Reallocation, and Volatility: International Evidence*
}

\author{
Simone Manganelli \\ European Central Bank
}

\author{
Alexander Popov ${ }^{\dagger}$ \\ European Central Bank
}

\begin{abstract}
This paper studies how financial development affects the volatility of GDP growth through the channel of sectoral reallocation. For 28 OECD countries over the period 1970-2007, we construct a benchmark industrial portfolio that minimizes the economy's long-term volatility for a given level of long-term labor productivity growth. We find that financial development substantially increases the speed with which the observed industrial composition of output converges toward the benchmark. To overcome endogeneity concerns, we exploit sectoral sensitivities to financial deepening and exogenous liberalization events.

JEL classification: E32, E44, G11, O16

Keywords: Financial development, volatility, growth, diversification, mean-variance efficiency
\end{abstract}

\footnotetext{
${ }^{*}$ We thank Luc Laeven for sharing with us a variety of data. For useful comments, we thank Geert Bekaert, Enrica Detragiache, Charles Engel (the editor), Gabriel Fagan, John Fernald, Pierre-Olivier Gourinchas, Philipp Hartmann, Jean Imbs, Urban Jermann, Sebnem Kalemli-Ozcan, Dirk Krueger, Luc Laeven, Ross Levine, Leslie Lipschitz, Florencio Lopez-de-Silanes, Valerie Ramey, Sergio Rebelo, Rafael Repullo, Helene Rey, Peter Tufano, two anonymous referees, seminar participants at the ECB and the IMF, and conference participants at the 2010 Financial Intermediation Research Society Meeting, the National Bank of Poland Conference "Heterogeneous Nations and Globalized Financial Markets," the 2010 World Congress of the Econometric Society, and the 2011 Federal Reserve Bank of Chicago Annual International Banking Conference. The opinions expressed herein are those of the authors and do not necessarily reflect those of the ECB or the Eurosystem.

${ }^{\dagger}$ Corresponding author. European Central Bank, Financial Research Division, Sonnemannstrasse 22, D-60314 Frankfurt, email: Alexander.Popov@ecb.int
} 


\section{Introduction}

A large empirical literature over the past two decades has documented important growth benefits of financial development, but does higher growth come at the cost of increased economic volatility? While frequent financial crises in both developing and developed countries seem to suggest that the answer is "yes," the literature has identified two channels through which financial development can in fact reduce growth volatility. The first is the stabilization of intrasectoral output. Braun and Larrain (2005) and Raddatz (2006) use sectoral data on value added in large cross-sections of countries, and find that financial development lowers output volatility, more so in financially vulnerable sectors. As long as industrial shares and the correlations of sectoral output remain constant, these results imply a reduction in overall volatility. Second, financial development can induce an intersectoral reallocation of output away from sectors with a large contribution to aggregate volatility. This argument relies on a portfolio optimization mechanism a la Markowitz (1952) that exploits the correlations in sectoral returns across sectors. Using this approach, Acharya et al. (2011) show that branching deregulation in the United States has reduced state business-cycle volatility through a reallocation of output towards sectors with a large optimal weight implied by mean-variance efficiency.

This paper contributes to the literature by testing the second mechanism in an international context. In theory, diversification of output through the channel of volatility-reducing reallocation may not be a universal outcome of financial development if it depends on the superior institutional features of a particular country (the United States). Our results strongly suggest that this is not the case. Our approach is as follows. We first acquire data on output and employment for nine sectors for 28 OECD countries starting in 1970. We use these data to construct, for each country, a benchmark set of optimal sectoral employment shares, which minimizes long-term aggregate volatility for a given level of long-term growth. In particular, a sector's optimal share is derived from an argument that depends on the sector's own relative labor productivity and labor productivity growth, as well as on the volatility and the correlation with other sectors thereof. We then estimate the effect of financial development (captured in the main tests by the level of private credit to GDP) over time on the speed with which the economy's actual industrial composition converges to the benchmark. The evidence strongly suggests that financial development has accelerated 
this convergence. A two-standard-deviation increase in financial development results in a roughly $0.6 \%$ higher annual speed of convergence towards the efficient industrial composition. By means of illustration, if in 1970 Italy had as deep credit markets as the United States, then in 2007 its economy would have exhibited a sectoral composition associated with $10 \%$ lower volatility than the realized one, for the same level of realized labor productivity level and growth.

We address a number of concerns about the interpretation and robustness of our main findings. First, our results suggest that developed financial markets reduce long-term volatility by exploiting the correlations across sectors in labor productivity level and growth, rather than by simply increasing the weight of low-volatility sectors. An alternative mechanism implied by our results could be the following: finance reallocates resources towards fast-growing sectors, and so they become larger. Because large sectors are more stable, aggregate volatility declines over time. If this is the case, the correlations in sectoral returns would be irrelevant for the evolution of aggregate volatility, and we could simply be capturing a finance-induced reallocation towards (ex-post) low-volatility sectors. However, we show that when in the construction of the optimal industrial portfolio we artificially set the correlations across sectors to zero, the effect of financial development on the speed of convergence disappears. This result sheds new light on how financial development affects the economy. In particular, Wurgler (2000) argues that in financially developed economies booming sectors grow faster by generating higher investment, and Imbs (2007) shows that high-growth sectors tend to have higher volatility. We argue that these results are not incompatible with lower long-term aggregate volatility if at the same time output is reallocated away from sectors with a large contribution to aggregate volatility through the growth correlations mechanism.

The second concern is methodological. In the calculations of the mean-variance efficiency frontier, we implicitly assume that there are no structural breaks in the underlying stochastic process generating the unconditional frontier. While this can be true for economies with mature financial markets, many of the countries in our sample underwent financial liberalization during our sample period, possibly inducing a structural break in the sectoral returns. We account for this possibility by repeating our tests on a subsample of countries that liberalized their financial markets prior to the start of the sample period. We also calculate benchmark industrial allocations for more than one period per country (before and after the start of the "Great Moderation"). Our main estimates are qualitatively unaltered by these alternative approaches. 
Third, our results might be biased by a demand-driven move over the development cycle towards sectors with lower intrinsic volatility, like health provision, education, and government services (Koren and Tenreyro, 2007). They also could be related to the increase in size of the service sector fueled by a finance-promoted shift towards more capital-intensive technologies (Larrain, 2010). In that regard, the estimated positive effect of finance on convergence toward the benchmark allocation might be biased by a preference-driven or a technology-driven global move away from intrinsically volatile sectors. We address this concern by employing a panel specification with industry-year and country-industry fixed effects. This accounts for convergence-affecting mechanisms that are time-invariant for each sector in each country or that display sector-specific trends. Consequently, we are able to isolate the contribution of the time-varying country-specific component of finance to convergence.

Fourth, our estimates can be contaminated by omitted variables bias and reversed causality. For example, unobserved risk aversion or propensity to save might be driving both output reallocation and financial development. Alternatively, if financial services have a "luxury good" component, richer and better diversified economies would demand more of them. We address these concerns in a number of ways. First, in the spirit of Rajan and Zingales (1998), we exploit the variation across sectors in natural technological dependence on external finance, and show that convergence is faster for sectors that are naturally sensitive to credit market development. We also replace our continuous measure of financial development with dummy variables proxying for financial liberalization. This de jure measure is largely exogenous (Bekaert et al., 2005) and so it should additionally address concerns about the endogeneity of financial development. Finally, we show that convergence is at play in both capital-intensive and labor-intensive sectors, assuaging concerns about our results being driven by the fact that countries that are better diversified and at the same time derive a larger share of economic output from more capital intensive industries can demand larger financial sectors.

Our results inform the literature on the effect of financial development on economic volatility. For example, Hellmann et al. (2000) argue that financial development fuels competition and erodes banks' franchise value, thus incentivizing banks to take on more risk. Since governments cannot commit to not provide bailouts in times of crises, banks have incentives to gamble for resurrection, exacerbating the business cycle. Alternatively, financial development can reduce volatility by 
alleviating information asymmetries, thus reducing the role of borrower's net worth in the amplification of shocks (Aghion et al., 1999; Caballero and Krishnamurty, 2001). ${ }^{1}$ Empirical work using various sample periods and proxies for financial development has presented evidence to both ends. For instance, Easterly et al. (2000) find that financial development reduces output volatility, and Bekaert et al. (2006) find that financial liberalization reduces consumption volatility. At the same time, Kaminsky and Reinhart (1999) link credit growth to crises, and Beck et al. (2006) find no correlation between financial development and long-term volatility. Using sectoral data, Braun and Larrain (2005), Larrain (2006), and Raddatz (2006) present evidence that financial development lowers output volatility in manufacturing industries with high external dependence and liquidity needs. However, Levchenko et al. (2009) show that financial liberalization increases volatility, more so in financially vulnerable sectors. We contribute to this literature by estimating a robust negative association between financial development and aggregate volatility in a large cross-section of countries and by demonstrating the link between the reduction in volatility and the finance-driven evolution of the economy's industrial composition.

We also relate to a vast empirical literature on the finance and growth nexus. ${ }^{2}$ This literature documents a significant, positive, causal effect of finance on economic growth, both at the country level (e.g., Levine and Zervos, 1998; Beck et al., 2000; Bekaert et al., 2005) and at the sector level (e.g., Rajan and Zingales, 1998; Fisman and Love, 2007; Gupta and Yuan, 2009). ${ }^{3}$ This literature usually abstracts from the effect of finance on volatility. In comparison, we use a mean-variance efficiency approach to study how financial development affects growth and volatility simultaneously.

Finally, our paper is related to a growing body of literature that has focused on the link between economic growth and volatility of growth. From a theoretical point of view, the link is ambiguous. For example, endogenous growth is affected by business-cycle volatility negatively in the presence of diminishing returns to investment, and positively in the presence of precautionary savings, creative destruction, liquidity constraints, or high-return high-risk technologies. The combined evidence implies that growth and volatility tend to relate negatively at the country level (Ramey and Ramey,

\footnotetext{
${ }^{1}$ In general, the effect of finance on the variability of output is expected to vary depending on whether monetary or real shocks are at play (Bachetta and Caminal, 2000) and on whether the real shocks are due to shifts in credit demand or in credit supply (Morgan et al., 2004).

${ }^{2}$ The idea to link finance and growth in a causal way traces back to Schumpeter (1912) and later Goldsmith (1969) and McKinnon (1973), but the modern impetus for studying the nexus is usually attributed to King and Levine (1993a, 1993b).

${ }^{3}$ For recent surveys, see Beck et al. (2001), Wachtel (2001), and Levine (2005).
} 
1995), ${ }^{4}$ but positively at the industry level (Imbs, 2007). This apparent contradiction is resolved by noticing that the positive correlation between risk and return at the sector level is more than compensated in the aggregate by the negative correlations between sectoral growth rates. This approach of distinguishing between the country-specific and sector-specific elements of volatility relates to a seminal contribution by Koren and Tenreyro (2007), who show that in large part the reduction of country-specific volatility over the development cycle is due to the reallocation of output to sectors with intrinsically lower volatility. Our paper contributes to this line of research in two important ways. First, we show that financial development is an important driver of the reduction of country-specific volatility. Second, we argue that a large portion of the reduction in volatility over the development cycle comes from a reallocation across sectors rather than from a reduction in intrasectoral volatility.

The rest of the paper is structured in the following way. Section 2 presents our empirical methodology and describes the data. Section 3 presents the empirical results together with endogeneity and robustness tests. Section 4 concludes with a discussion of the main results and of possible extensions.

\section{Empirical methodology}

\subsection{Economic interpretation of mean variance utility optimization}

Ignoring consumption-saving decisions, assume that a representative agent chooses the sectoral employment shares in the economy, $\mathbf{l}_{t}$, to maximize a Constant Relative Risk Aversion (CRRA) utility function:

$$
\max _{\left\{\mathbf{1}_{t}\right\}_{t=0}^{\infty}} E_{0} \sum_{t=1}^{\infty} \beta^{t} U\left(C_{t}\right)=E_{0} \sum_{t=1}^{\infty} \beta^{t} \frac{C_{t}^{1-\gamma}}{1-\gamma}
$$

s.t.

$$
C_{t+1}=Y_{t+1}\left(\mathbf{l}_{t}\right), \forall t
$$

$\beta$ is the discount rate, and $\gamma>1$ is the coefficient of relative risk aversion. $Y_{t+1}$ is the random flow of per capita income at $t+1 . \mathbf{l}_{t}=\left[\begin{array}{llll}l_{1 t}, & l_{2 t}, & \ldots, & l_{S t}\end{array}\right]^{\prime}$ is a vector capturing relative sectoral employment $l_{s t}=\frac{L_{s t}}{L_{t}}$, for each sector $s \in\{1, \ldots, S\}$, where $L_{s t}$ is total employment at time $t$ in

\footnotetext{
${ }^{4}$ Empirical research on the link between GDP growth and volatility as a rule abstracts from the role of financial development. In an important deviation from this rule, Kose et al. (2006) show that financial integration has weakened the negative relationship between growth and volatility.
} 
sector $s$ and $L_{t}$ is total aggregate employment at time $t$. By definition, $\sum_{s=1}^{S} l_{s t}=1$.

Define $Y_{t+1}=Y_{t} \exp \left\{y_{t+1}\right\}$, where $y_{t+1}$ is the exponential rate of growth of per capita income. We now link $y_{t+1}$ to fundamental factors, by first writing per capita income (or output per worker) as a function of sectoral employment shares $\left(l_{s t}\right)$ and sectoral labor productivity $\left(Y_{s, t+1}\right)$ :

$$
Y_{t+1}=\sum_{s=1}^{S} l_{s t} Y_{s, t+1}
$$

where employment is decided at time $t$. Assume that sectoral labor productivity grows at the rate $y_{s, t+1}$ such that

$$
Y_{s, t+1}=Y_{s t} \exp \left\{y_{s, t+1}\right\}
$$

We also assume that the growth rate $y_{s, t+1}$ is independent of $Y_{s t}$, as this allows breaking down the utility maximization into period-by-period maximization. Using the approximations $\ln X \approx X-1$ and $\exp \{X\}=X+1$, the rate of growth can be written as:

$$
\begin{aligned}
y_{t+1} & =\ln \left(Y_{t+1} / Y_{t}\right) \\
& =\ln \sum_{s=1}^{S} l_{s t} \frac{Y_{s t}}{Y_{t}} \exp \left\{y_{s, t+1}\right\} \\
& \approx \sum_{s=1}^{S} l_{s t} \frac{Y_{s t}}{Y_{t}} \exp \left\{y_{s, t+1}\right\}-1 \\
& \approx \sum_{s=1}^{S} l_{s t} \frac{Y_{s t}}{Y_{t}}\left(y_{s, t+1}+1\right)-1 .
\end{aligned}
$$

Denote $x_{s, t+1} \equiv \frac{Y_{s t}}{Y_{t}}\left(y_{s, t+1}+1\right)$. By construction, $x_{s, t+1}$ includes both a level component of relative labor productivity and a growth component of labor productivity. We assume that $\mathbf{x}_{t+1}=$ $\left[x_{1, t+1}, \quad x_{2, t+1}, \quad \ldots, \quad x_{S, t+1}\right]^{\prime}$ is normally distributed:

$$
\mathbf{x}_{t+1} \sim N(\boldsymbol{\mu}, \boldsymbol{\Sigma})
$$

Note that if a random variable $X$ is normally distributed, $X \sim N\left(\mu, \sigma^{2}\right)$, then by the properties of lognormality, $E[\exp (X)]=\exp \left(\mu+\frac{1}{2} \sigma^{2}\right)$. We also note that $Y_{t+1}^{1-\gamma}=\left(Y_{t} \exp \left\{y_{t+1}\right\}\right)^{1-\gamma}=$ 
$\exp \left\{(1-\gamma) \ln \left(Y_{t}\right)+(1-\gamma) y_{t+1}\right\}$. Then, using (5), expected utility can be rewritten as:

$$
\begin{aligned}
E_{t}\left[U\left(Y_{t+1}\left(\mathbf{l}_{t}\right)\right)\right] & =E_{t}\left[\frac{Y_{t+1}^{1-\gamma}}{1-\gamma}\right] \\
& =E_{t}\left[\frac{\exp \left\{(1-\gamma) \ln \left(Y_{t}\right)+(1-\gamma) y_{t+1}\right\}}{1-\gamma}\right] \\
& =\frac{\exp \left\{(1-\gamma) \ln \left(Y_{t}\right)+(1-\gamma) \mathbf{l}_{t}^{\prime} \boldsymbol{\mu}+(1-\gamma)^{2} \frac{1}{2} \mathbf{l}_{t}^{\prime} \boldsymbol{\Sigma} \mathbf{l}_{t}-(1-\gamma)\right\}}{1-\gamma}
\end{aligned}
$$

Because $1-\gamma<0$, by monotonicity, maximizing $E_{t}\left[U\left(Y_{t+1}\left(\mathbf{l}_{t}\right)\right)\right]$ is equivalent to minimizing the function

$$
\widetilde{U}\left(\mathbf{l}_{t} ; \boldsymbol{\mu}, \boldsymbol{\Sigma}\right)=(1-\gamma) \ln \left(Y_{t}\right)+(1-\gamma) \mathbf{l}_{t}^{\prime} \boldsymbol{\mu}+(1-\gamma)^{2} \frac{1}{2} \mathbf{l}_{t}^{\prime} \mathbf{\Sigma} \mathbf{l}_{t}-(1-\gamma)
$$

Neglecting the constants and $Y_{t}$, which is known at time $t$, and dividing by $(1-\gamma)$, the representative agent's optimization problem becomes:

$$
\max _{\mathbf{l}_{t}} \quad \mathbf{l}_{t}^{\prime} \boldsymbol{\mu}-\frac{1}{2}(\gamma-1) \mathbf{l}_{t}^{\prime} \boldsymbol{\Sigma} \mathbf{l}_{t}
$$

The coefficient multiplying the variance term is positive; therefore, (9) is a standard mean variance problem, where the choice variable is relative employment in each sector $s$ and the random variable is proportional to the rate of productivity growth.

\subsection{Constructing the optimal allocation benchmark}

The program (9) is a standard mean-variance efficiency (MVE) problem in the spirit of Markowitz (1952). It boils down to computing optimal sector-specific employment shares that would minimize distance to the MVE frontier. In principle, it would be possible to compute a time-varying, conditional efficient frontier, for instance, by modeling the variance covariance matrix with a multivariate GARCH model. However, since we are interested in the long-run growth and risk opportunities of the economy, it is more appropriate to use the unconditional means and variances. Both approaches rest on the implicit assumption that there are no structural breaks in the underlying stochastic process.

To circumvent the dependence of the efficient benchmark on the coefficient $\gamma$, we reformulate 
the optimization problem in the following way, for each country $c$ :

$$
\begin{array}{||ll}
\min _{\mathbf{l}_{c t}} & \mathbf{l}_{c t}^{\prime} \boldsymbol{\Sigma}_{c} \mathbf{l}_{c t} \\
\text { s.t. } & \mathbf{l}_{c t}^{\prime} \boldsymbol{\mu}_{c} \geq \tilde{\mathbf{l}}_{c t}^{\prime} \boldsymbol{\mu}_{c} \\
& \mathbf{l}_{c t} \geq 0 \\
& \sum_{s=1}^{S} l_{c s t}=1,
\end{array}
$$

where we have added an additional subscript for country, relative to the notation so far. $\tilde{\mathbf{l}}_{c, t}$ denotes the vector of observed employment shares for country $c$ at time $t$. The nonnegativity constraint reflects the fact that it is not economically meaningful to have negative weights for the employment shares in this context. This optimization programme delivers the point on the frontier that minimizes the country's volatility of an argument, which is proportionate to relative labor productivity and labor productivity growth, for the realized level of relative labor productivity and labor productivity growth. ${ }^{5}$ The distance between such a point and the actual levels of volatility can be interpreted as a measure of allocative efficiency, because it measures by how much a country could have reduced its macroeconomic volatility, while achieving the same level of growth, by simply allocating differently its resources across sectors.

Denoting the vector solution to this problem by $\mathbf{l}_{c, t}^{*}$, and by $l_{c, s, t}^{*}$ the individual elements of this vector, we can construct the following measure of country's allocative efficiency:

$$
D_{c, s, t}=\left|l_{c, s, t}^{*}-\tilde{l}_{c, s, t}\right|
$$

where $\tilde{l}_{c, s, t}$ are the observed actual allocations. $D_{c, s, t}$ is the distance between optimal and actual employment shares for each sector component of a country at time $t$.

A potential problem with the framework we employ is the strong assumption that labor productivity itself is not affected by reallocation (i.e., it is exogenous to the sectoral composition). However, it has a number of advantages compared with the framework used by Acharya et al. (2011), who use growth in value added (rather than in labor productivity) to calculate the MVE sectoral allocation. In particular, in their framework the growth rate of value added is mismeasured

\footnotetext{
${ }^{5}$ The variance-covariance matrix is not invertible when $\mathrm{T}<=\mathrm{N}$, and even when $\mathrm{T}$ is only slightly larger than $\mathrm{N}$, the variance-covariance matrix is imprecisely estimated. Throughout the paper, we use an industrial classification, for which industries are aggregated at a level sufficient to give precise estimates of the variance-covariance matrix.
} 
by construction because it already includes sectoral reallocation (moving a worker from sector A to sector B increases value added in sector B by the labor productivity of that sector). ${ }^{6}$ This alternative mechanism can yield the tautological prediction that high-growth sectors become larger over time or potentially converge faster to the MVE frontier. Nevertheless, in one of our robustness checks, we derive the distance defined in (11) from a version of the optimization program (10), where we use growth in value added instead of growth in value added per worker.

Figures 1, 2, and 3 illustrate three different growth-volatility profiles over time. The actual industrial composition in the United States (Figure 1) and in the euro area (Figure 2) has strongly converged over time toward the benchmark allocation in the volatility dimension, while the Japanese economy experienced steady divergence throughout the sample period (Figure 3). We also note a mechanical property of mean-variance efficiency: the actual industrial composition in a number of countries (such as Italy) lies fully under the tip of the MVE frontier, and so in these cases distance to frontier in the volatility dimension coincides with distance to the minimum variance portfolio (the tip of the frontier).

\subsection{Finance and convergence: Empirical model}

We study the link between finance and the economy's growth-volatility profile using a standard convergence framework. Our convergence test estimates the speed with which the actual employment share of sector $s$ in country $c$ converges to its optimal share in financially more developed countries. This allows us to directly look into the issue of reallocation and examine which sectors move faster to their implied optimal weights following financial development. Formally, we estimate the following convergence equation:

$$
D_{c, s, t}=\alpha D_{c, s, t-1}+\beta D_{c, s, t-1} \cdot \text { Finance }_{c, t}+\gamma \text { Finance }_{c, t}+\delta \phi_{c s}+\eta \phi_{s t}+\varepsilon_{c, s, t},
$$

where Finance $_{c, t}$ is equal to a standard measure of beginning-of-period financial market development, and $D_{c, s, t}$ is defined as in (11). ${ }^{7}$ Our coefficient of interest is $\beta$ : if $\beta<0$, then greater

\footnotetext{
${ }^{6}$ See Caselli (2005) on how reallocating from less productive to more productive sectors may affect aggregate productivity.

${ }^{7}$ It is important to note that $(12)$ can be rewritten as

$$
D_{c, s, t}=\alpha D_{c, s, t-1}+\left(\beta D_{c, s, t-1}+\gamma\right) \cdot \text { Finance }_{c, t}+\delta_{c} \cdot \phi_{s}+\eta_{t}+\varepsilon_{c, s, t},
$$

and so the full effect of finance on distance to the allocative efficiency frontier is given by $\beta D_{c, s, t-1}+\gamma$. For example,
} 
financial development is associated with faster convergence toward the benchmark allocation. ${ }^{8}$ The inclusion of country-sector fixed effects $\left(\phi_{c s}\right)$ allows us to net out any unobservable country-sector specific time-invariant influences (such as the technological specificity of the oil extraction industry in Norway). The inclusion of industry-year fixed effects $\left(\phi_{s t}\right)$ allows us to purge our estimates from the effect of demand-driven or technology-driven industry-specific trends (for example, in the context of the "Great Moderation"). We thus aim to isolate the within-country effect of financial development..$^{9}$

The relationship between financial market size and the economy's growth-volatility profile is illustrated in Figure 4, which plots each individual country's autoregressive annual speed of convergence to the benchmark industrial allocation over the sample period against its initial ratio of private credit to GDP, for the cross-section of OECD countries. ${ }^{10}$ Clearly, the correlation is strongly positive. Countries with initially deeper credit markets - typically Anglo-Saxon ones experienced a larger annual reduction in distance to the optimally diversified benchmark over the past four decades than did less financially developed countries (typically Mediterranean and postcommunist economies). Thirteen percent of the cross-country variation in the speed of convergence toward the benchmark industrial allocation is explained by the size of financial markets.

There are two conceptual issues with our empirical framework. First, while $\beta<0$ in (12) would indicate faster convergence toward the MVE frontier in the volatility dimension, it is still possible that financially developed countries are simply converging faster to a higher level of distance. Denoting by $\bar{D}_{c, s}$ the steady-state level of distance to MVE frontier and by $C$ the sum of fixed effects, (12) can be rearranged as:

if both $\beta$ and $\gamma$ are negative, then more finance decreases distance to frontier, but if $\beta<0$ and $\gamma>0$, then the total effect of finance depends on $D_{c, s, t-1}$, and for low levels of $D_{c, s, t-1}$, finance could lead to divergence even if $\beta<0$.

${ }^{8}$ As pointed out by Acharya et al. (2011), the frontier is estimated with an error, and hence there is an attenuation bias in estimating convergence. This works against finding an effect and hence what we see in the data should be interpreted as a lower bound for the true effect. In addition, as shown by Jagannathan and Ma (2003) in the context of mean-variance allocation, imposing nonnegative constraints significantly reduces the impact of estimation error.

${ }^{9}$ We have estimated the equivalent of Equation (12) using country-level aggregates toward the optimal benchmark. This results in insignificant coefficients at the standard condifence levels. Our conjecture is that this is due to the loss of power associated with the considerably reduced sample size.

${ }^{10}$ We define the autoregressive annual speed of convergence as $1-\alpha_{c}$, where $\alpha_{c}$ denotes the estimate from the regression

$D_{c, t}=\alpha_{c} D_{c, t-1}+\varepsilon_{c, t}$
for each country $c$ in the sample, where $D_{c, t}=\frac{1}{9} \sqrt{\sum_{s=1}^{9}\left(D_{c, s, t}\right)^{2}}$ for the nine sectors in our sample. 


$$
\bar{D}_{c, s}=\frac{\gamma \text { Finance }_{c, t}+C}{1-\alpha-\beta \text { inance }_{c, t}} .
$$

Immediately,

$$
\frac{\partial \bar{D}_{c, s}}{\text { PFinance }_{c, t}}=\frac{\gamma(1-\alpha)+\beta \cdot C}{\left(1-\alpha-\beta \text { Finance }_{c, t}\right)^{2}} .
$$

The sign of the derivative, provided $\beta<0$ and given that $\alpha<1$, is indeterminate. In general, it is possible for faster-converging countries $(|\beta|$ large) to converge to a higher steady-state distance to frontier as long as they start farther from the frontier $(\gamma>0$ and large $)$ and their autoregressive speed of convergence $\alpha$ is not too high. This example shows that the question of the relationship between financial development and steady-state distance to frontier is an empirical one. Because we do not know the value of $C$, we cannot calculate the steady-state distance implied by our regression coefficients, but we can conjecture that each country's final distance to the MVE frontier is a crude approximation of the steady-state distance. In Figure 5, we plot final distance to frontier in our sample against beginning-of-period financial development. There is no discernible statistical association between the two, and less than $1 \%$ of the cross-country variation in the final distance to the benchmark industrial allocation is explained by the size of financial markets.

Second, we are assuming that the growth rate of labor productivity is measured correctly. In the presence of measurement error that varies systematically across countries (for example, if measurement error is lower in financially developed countries), our results might be biased. This is a caveat we need to acknowledge; at the same time, by including only OECD countries in the sample, we do make sure that measurement error is minimized. For example, Johnson et al. (2013) show that although the within-country difference in measured GDP growth rates between various revisions of the World Penn Tables is on average close to $2 \%$ for the rest of the world, it is only $0.1 \%$ for the sample of OECD countries.

We address the issue of the endogeneity of financial development in two alternative ways. First, we replace our continuous measure of finance with dummies equal to one after the year in which domestic financial markets were liberalized. It is commonly believed that policy decisions are more exogenous than volume measures of finance (Bekaert et al., 2005). Second, we employ the Rajan and Zingales (1998) approach of interacting our measure of finance with sector-specific proxies 
for technological sensitivity to financial development, namely, "natural" dependence on external finance and "natural" share of young firms. By identifying one channel via which finance should speed convergence, we aim to purge the possible bias in our estimates induced by simultaneity. We also show that convergence happens for both capital-intensive and labor-intensive sectors, ruling out the possibility that countries that are better diversified and at the same time derive a larger share of economic output from more capital-intensive industries can demand larger financial sectors.

\subsection{Data}

To compute levels of relative labor productivity and labor productivity growth rates at the sectoral level, we employ data on nominal value added - which we deflate to get real values and on employment from the STAN Database for Structural Analysis. The data cover 28 countries starting at best in $1970 .{ }^{11}$ The data are decomposed into nine SIC 1-digit sectors. Although we lose substantial sectoral variation with nine industries, disaggregating the data by SIC 1-digit industries serves two important purposes. For one, we thus make sure that we do not include sectors with negligible employment share in the calculation of the benchmark allocation of output across sectors. Second, the MVE calculations hinge on a dimensionality restriction, namely, that the number of years of data available should be higher than the number of sectors. Thus, we are unable to construct benchmark output allocations for countries for which data start after 1987 if we focus on a larger set of 2-digit industries. It is also worth noting that, if anything, aggregation into a set of so coarsely defined sectors makes it harder rather than easier to detect an effect of finance on the reallocation of resources across economic activities. ${ }^{12}$

Two data clarifications are in order. First, the level of disaggregation follows arbitrary statistical conventions, for which reason some activities are recorded more coarsely than others. If the economy tends to specialize, at later stages of development, in sectors that are more finely recorded, a mechanical relation between financial development and diversification can emerge. Second, while UNIDO has been the preferred dataset in the finance and growth literature, it only includes data

\footnotetext{
${ }^{11}$ Coverage varies across countries. While for the majority of the countries (16) the data start in the 1970s, for eight countries (Czech Republic, Germany, Greece, Hungary, Iceland, Poland, Slovakia, and Switzerland) they only start in the 1990s.

${ }^{12}$ For each country-sector-year, data on labor productivity, relative labor productivity for each country-year, and on the annual growth rate of labor productivity, are used to calculate the empirical counterpart to $x_{s, t+1}$ defined in Section 2.1. It is worth noting that most of the variation in $x_{s, t+1}$ comes from variations in relative labor productivity rather than from variations in the growth rate of sectoral labor productivity.
} 
on the manufacturing sector, and so STAN is more suited to studying optimal reallocation in the context of the major shift during our sample period from manufacturing towards services.

The financial variables used in this paper come from two different sources. The main measure of financial markets development is private credit / GDP. The value of total credits by financial intermediaries to the private sector goes into the numerator (lines $22 \mathrm{~d}$ and $42 \mathrm{~d}$ in the International Financial Statistics), and so this measure excludes credits issued by the central banks. The reason for this exclusion is that in many cases the latter is likely to be determined by political considerations rather than by economic considerations. The variable also excludes credit to the public sector and cross-claims of one group of intermediaries on another. Finally, it counts credit from all financial institutions rather than counting only deposit money banks. The data on this variable come from Beck et al. (2013) and are available for all 28 countries in the data set.

While the main measure of domestic financial development considered in the paper is ubiquitous in empirical research, it is intrinsically likely to contain measurement error. It is difficult to capture all aspects of financial development in one empirical proxy. Moreover, there are idiosyncratic differences across countries in the availability of unobservable sources of working capital, such as trade credit or family ownership. To confront these issues, we use in robustness tests data on equity market size (stock market capitalization / GDP), bond market size (private + public bond market capitalization / GDP), as well as various measures of financial integration.

We also address the issue of the endogeneity of any volume measure of finance to economic development by employing a de jure measure of financial development in addition to the de facto measure. In practice, we replace private credit / GDP with information on banking sector liberalization dates. This alternative indicator is constructed by assigning a value of zero for the years in which the country's domestic credit market was not liberalized, and one for the years after it became liberalized. The indicator comes from Bekaert et al. (2005). ${ }^{13}$

Table 1 summarizes average actual and optimal sectoral employment shares for the nine SIC 1-digit sectors in the dataset. We find that three of the nine sectors ("Manufacturing;" "Wholesale and Retail Trade and Restaurants and Hotels;" and "Community, Social, and Personal Services") together account for $68 \%$ of the "optimal" sectoral portfolio implied by long-term labor productivity

\footnotetext{
${ }^{13}$ See Appendix Table 1 for data on private credit and for credit market liberalization events. See Appendix Table A7 for all variables and sources.
} 
growth, volatility, and cross-sectoral correlations. Our estimates also imply that the actual share of a sector can be considerably higher than the optimal share. For example, "Finance, Insurance, Real Estate, and Business Services" accounts for a ninth of overall employment, whereas in an MVE-efficient world it should only account for $3.1 \%$ on average.

In Table 2, we look at the country-specific discrepancy between actual and optimal sectoral weight, for the same nine SIC 1-digit sectors in the dataset. The table uncovers striking differences across sectors and countries between actual and MVE-implied industrial composition. For example, the actual share of employment in "Finance, Insurance, Real Estate, and Business Services" in Luxembourg is higher than the optimal share by 17 percentage points, and the actual share of employment in "Manufacturing" in Italy is 25 percentage points higher than the optimal share. "Community, Social, and Personal Services," which is, on average, "too small" according to our MVE criterion, is at the other extreme. For example, $33 \%$ of U.S. workers are employed in "Community, Social, and Personal Services," whereas in an MVE-consistent world they should be almost three times as many.

\section{Empirical results}

This section is split into four subsections. The first (3.1) investigates the effect of finance on the economy's growth-volatility profile. The second (3.2) looks at the nature of sectoral reallocation and addresses various endogeneity issues associated with faster convergence toward the benchmark industrial allocation. The third (3.3) considers alternative measures of industrial diversification. The fourth and final one (3.4) presents robust measures of financial development and compares the effect of financial development to that of financial and trade integration.

\subsection{Finance and convergence}

The main empirical question addressed in this paper is whether finance accelerates the economy's convergence toward the benchmark MVE-implied industrial composition. We report the estimates of (12) in Table 3. Column (1) reports the estimates from an OLS regression. The regressions include industry and year dummy interactions because we want to net out any demand-driven or technology-driven industry-specific trends. They also include a set of country and industry dummy interactions to account for the fact that low-volatility sectors can be a superior good (Koren and Tenreyro, 2007), or that sectors with a higher initial distance can experience faster convergence. The 
estimate of the direct autoregressive coefficient on distance to frontier so defined, $\alpha$, implies a yearly reduction of around $3.6 \%$ in our sample. Crucially, financial development interacts negatively with distance to frontier, as implied by the estimate of the coefficient $\beta$. Our estimates thus suggest that financial development has a positive effect on the speed with which countries converge to their efficiency frontier. Numerically, holding initial distance to frontier constant, a two-standarddeviation increase in financial development results in an increase of about $0.6 \%$ in the speed of convergence toward the frontier. The estimate is significant at the $5 \%$ statistical level.

In Column (2), we estimate (12) using a GMM Arellano-Bond (1991) estimator rather than a OLS procedure. We do so to account for the presence of a lagged dependent variable in dynamic panel data. In unreported regressions, we also estimate the GMM estimator introduced by Blundell and Bond (1998); doing so corrects for the bias arising in fixed effects estimations in dynamic models. This correction is standard in panel estimation of the finance and growth nexus (e.g., Bonfiglioli, 2008; Acharya et al., 2011). Our main result continues to hold, and the estimate is significant at the $1 \%$ statistical level.

An immediate caveat is that the benchmark allocation of output itself may have been affected by financial development. If finance affects both growth and volatility, as the literature on finance and growth has argued, then initial financial underdevelopment will result in artificially low early growth and high early volatility. Structural breaks in financial development, therefore, will remove constraints to growth and lower volatility, and that would effectively contaminate our long-term benchmark. Koren and Tenreyro (2007) argue that the same global sectoral shock will have a lower aggregate effect in financially developed economies because they have the infrastructure in place which allows them to hedge against such shocks. By this rationale, financial development can affect not just the speed of convergence toward an MVE frontier but also long-term labor productivity growth and volatility, and hence the frontier itself.

One solution is to calculate a "clean" frontier in which long-term labor productivity growth, volatility, and correlations have not been affected by finance midcycle. In the first column of Table 4, we repeat the empirical tests reported in Table 3, but this time we estimate (12) on a restricted sample of countries that liberalized domestic credit markets before the beginning of the sample period. In this way we make sure that we are measuring convergence toward an allocative efficiency benchmark based on unconstrained long-term growth and volatility, and not to one contaminated 
by the initial underdevelopment of financial markets. The estimate of the speed of convergence is once again significant at the $5 \%$ statistical level, and the magnitude of the coefficients is if anything marginally higher than that implied by the estimates from the full sample.

In Column (2) of Table 4, we perform another version of this test. Namely, for all countries for which data are avaiable over a sufficiently long period of time, we calculate two separate MVE frontiers, one for 1970-1988 and another for 1989-2007. Labor productivity growth, volatility, and correlations are thus calculated over two 19-year periods. The sample split also roughly coincides with the start of the structural shift toward lower aggregate volatility known as the "Great Moderation." Finance continues to exert a significant effect on the speed of convergence toward benchmark industrial composition even for this alternative construction of the MVE frontier.

In all, Tables 3 and 4 imply that part of the effect of finance is a restructuring of output towards sectors which are far from their optimal weight. This process partially captures the effect of finance on the natural disappearance of obsolete sectors. In theory it could be that the total effect depends on initial conditions, and so the overall effect of finance is confounded by a very inefficient initial sectoral allocation, limiting the effect of diversification as in Acemoglu and Zilibotti (1997). The effect of finance also could be confounded by other political economy forces, for instance, large inefficient sectors might be using lobbying tools to acquire government resources and continue existing while their implied weight might be zero. We investigate these possibilities later on.

It is important to point out that finance has a direct positive effect on the distance to the optimal industrial benchmark. This implies that close to the frontier $\left(D_{c, s, t} \rightarrow 0\right)$, more finance is associated with divergence from the frontier rather than with convergence toward the frontier. At the same time, this effect is not statistically significant in the OLS case.

\subsection{Addressing the endogeneity of finance}

We have so far established a positive correlation between financial development and convergence toward a benchmark allocation of industrial output defined in the sense of mean-variance efficiency. However, we have left the question of causality largely unanswered. Given the evidence so far, the argument can still be made that financial development and diversification are simultaneously driven by factors unobservable to the econometrician. For example, the uncovered empirical pattern could be due to the fact that more optimally diversified economies consist of large capital-intensive 
sectors, which in turn need a large financial industry. Alternatively, unobservable factors such as the propensity to save, might be driving both the size of financial markets and diversification patterns. In this subsection, we discuss strategies whereby we deal with these concerns.

\subsubsection{The nature of reallocation: Which sectors converge faster?}

We first address the issue of omitted variable bias by employing the methodology first introduced by Rajan and Zingales (1998). They document the significance of the interaction term between a country-specific component of financial development and an industry-specific component of financial dependence. The innovation of the method is in that they use a U.S. benchmark to construct an exogenous measure of financial dependence in their sample of countries that excludes the United States. This empirical strategy alleviates concerns about the ability of financial development to anticipate growth, volatility, or the extent of industrial diversification. It also addresses questions about the joint determination of financial development and growth by a third, unobservable factor.

A natural channel via which we expect finance to exert a causal effect on convergence toward the frontier is the sector's natural dependence on external finance. The idea is that financial development is more likely to reallocate investment towards a sector that needs to become larger in an MVE sense if this sector is naturally sensitive to developments in financial markets. Empirically, firms in such sectors are likely to finance a large share of their operating expenses with external funds (Rajan and Zingales, 1998). Such sectors are also likely to exhibit a high share of small and young firms in equilibrium (e.g., Klapper et al., 2006; Aghion et al., 2007; Acharya et al., 2011).

We proceed to constructing industry benchmarks that capture these technological characteristics. As our benchmark for external dependence, we look at mature Compustat firms in the United States, and we take industry median value of the sum across years of total capital expenditures (Compustat item \#128) minus cash flow from operations, that is revenues minus nondepreciation costs (Compustat item \#110), plus decreases in inventories and accounts receivable, plus increases in accounts payable. While this is clearly not only a measure of the industry's "natural" demand for credit but also one of dependence on other sources of external finance, like the corporate bonds market, Cetorelli and Strahan (2006) show that this benchmark is very highly correlated $(\rho=0.51)$ with actual use of bank finance by firms. This feature plus the fact that it is not skewed by constraints on the supply side makes the benchmark a powerful instrument for sensitivity to the supply 
of credit. As a second benchmark for sensitivity to financial development, we calculate the share of young firms (less than two years old) for each sector using data from the Dun and Bradstreet database, averaged for 1985-1995.

In Table 5, we re-estimate an updated version of (12), whereby we split the industries in the sample into low and high, in terms of external dependence (Columns (1) and (2)) and in terms of the share of young firms (Columns (3) and (4)). The estimates strongly imply that the results recorded so far apply mostly to the subsample of industries with a high dependence on external finance (Column (2)) and for industries with a high share of young firms (Column (4)). In the case of industries with low dependence on external finance (Column (1)) and of industries with a low share of young firms (Column (3)), the effect of finance on convergence toward the MVE frontier is not significant, albeit being still negative.

\subsubsection{Reversed causality}

We now proceed to addressing the issue of reversed causality. For example, countries can demand larger financial sectors if they are better diversified and at the same time derive a larger share of economic output from more capital-intensive industries. While this alternative explanation suggests that a reverse mechanism to the one we argue for is at play, it would still imply that the meanvariance framework is empirically relevant when it comes to understanding the relation between financial development and the specialization of production.

Nevertheless, we now proceed to check if the data provide empirical justification for this alternative story. We do so in Table 6, where we present estimates from a number of tests aimed at addressing the issue of reversed causality. First, we replace our preferred measure of financial development with liberalization dates of domestic credit markets, as per Appendix Table 1. Although the argument sometimes has been made that liberalization can be endogenous as policy makers can undertake it when the country is already starting on the path of higher growth, ${ }^{14}$ a policy measure is more exogenous to growth opportunities than is the volume measure we have used so far. Hence, we replace the financial proxy in (12) with a dummy variable equal to one after the year in which the country liberalized its credit markets. We find that countries have been converging to the MVE frontier faster in the years after credit markets liberalization (Column (1)), and this

\footnotetext{
${ }^{14}$ See Bekaert et al. (2007) for details.
} 
effect is significant at the $10 \%$ statistical level.

Another issue with our tests so far is that the financial sector is included both on the left-hand side and on the right-hand side of the estimation equation. To address this concern, in Column (2) we exclude the SIC 1-digit sector "Finance, Insurance, Real Estate, and Business Services" from the main tests. As argued before, our previous results might be biased by the fact that the proxies used for financial development increase simultaneously alongside the share of financial services on the left-hand side. The effect of credit market development, however, survives this procedure and is still significant at the $5 \%$ statistical level.

An alternative way through which this mechanism would manifest itself in the data is if one observed only capital-intensive sectors converging to their optimal weights, but not the laborintensive sectors. We address this issue in Column (3). In particular, we estimate a version of (12), where we have dropped the top three sectors in terms of capital intensity; these are the sectors in which labor compensation accounts for less than two-thirds of total production. ${ }^{15}$ The evidence suggests that capital-intensive industries converge to their optimal MVE-implied weight faster than the labor-intensive industries, as excuding the most capital-intensive sectors reduces the magnitude of the overall effect. Nevertheless, labor-intensive industries converge as well, implying that our results are not solely driven by a mechanism whereby more diversified economies derive a larger share of output from capital-intensive sectors.

Taken together, the estimates reported in Tables 5 and 6 point to the fact that while valid arguments can be made that our results are driven by omitted variable bias or by reversed causality, the positive effect of financial development on the speed of convergence toward a more diversified industrial composition in an MVE sense survives when we explicitly address these concerns.

\subsection{Optimal vs. "naive" diversification}

The virtue of our benchmark allocation of industrial output, based on the concept of meanvariance efficiency, is that it accounts simultaneously for labor productivity growth, volatility, and cross-sector correlations. In Table 7, we now contrast our results with those obtained by assuming away the importance of cross-sector correlations. In the first case, we estimate a benchmark frontier in which all covariance terms are set to zero. This transforms a mean-variance efficiency argument

\footnotetext{
${ }^{15}$ To calculate labor and capital intensities, we use the industry distribution of the annual ratio of total compensation to industrial production reported by Palacios (2011).
} 
into one in which finance targets sectors based solely on their individual Sharpe ratios. Such a framework fails to explain the full pattern of convergence of sector shares over time (Column (1)). This implies that the effect of finance on diversification is significant only when the covariance of returns is properly accounted for in an optimal portfolio sense. This point is important: our results show that financial development results in lower aggregate volatility not just through a reduction in intrasectoral volatility as in Braun and Larrain (2005) and Raddatz (2006) but also through a reallocation of resources away from sectors whose labor productivity growth pattern is highly correlated with the growth pattern of the rest of the economy.

Next, we contrast our measure of diversification based on allocative efficiency with a measure that defines diversification as an equal allocation of employment across sectors, $\frac{1}{N}$. This measure constitutes a "naive" concept of diversification, which ignores any considerations about growth, volatility, and cross-sector correlations. The corresponding measure of distance to frontier in this case is defined as $D_{c, s, t}=\left|\tilde{l}_{c, s, t}-\frac{1}{N}\right|$, where $N=9$. Column (2) reports the estimates of the coefficient on the interaction term in (12), where $D_{c, s, t}$ is calculated using this alternative approach. The result suggests that financial development has a negative effect on the speed with which the country allocation of output converges to a benchmark in which output is equally spread across the set of sectors available. However, this effect is only significant at the $10 \%$, suggesting that reallocation toward an MVE benchmark is a more powerful force at play than mechanical diversification towards a uniformly diversified industrial portfolio.

An immediate interpretation for this result is in the spirit of the U-shaped diversification pattern over the development path documented by Imbs and Wacziarg (2003). Our finding that for a set of industrialized economies, employment is reallocated as to minimize the volatility of labor productivity growth is not inconsistent with a development pattern in which in later stages the economy specializes to exploit pecuniary externalities and economies of scale. At the same time, the fact that economies with more efficient financial markets do not exhibit a more equal reallocation of resources across sectors is also consistent with a development path in which "naive" diversification does not evolve linearly over time.

Finally, we address the fact that volatility is bound from below by the minimum-variance portfolio (the tip of the mean-variance efficient frontier). Consequently, distance to the meanvariance frontier is bounded above by distance to the mean-variance portfolio. We note that for 
a number of countries, for a number of years, our measure of distance to frontier coincides with distance to the mean-variance portfolio. This portfolio is in some sense the most low-volatility one, and the distance to it simply measures the extent of diversification. In Column (3) we report the estimates from (12), where $D_{c, s, t}$ is calculated as the distance between each sector's actual share of the overall economy and its optimal share in the minimum-variance portfolio. The results confirm that financial development affects the speed of convergence toward the frontier using this metric, but the effect is not significant in the statistical sense.

\subsection{Robustness: Alternative measures of financial development, trade, and financial integration}

So far we have relied exclusively on the time series of the ratio of private credit to GDP to capture the country-specific evolution in financial depth. There are a number of problems with this measure that we now address in Table 8. For one, our main proxy for financial development excludes credit issued by the central bank. Such credit can be driven by political rather than economic consideration, but at the same time, central bank credit can be less endogenous to the evolution of industrial specialization. In Column (1), we re-estimate our main tests after adding the ratio of central bank credit to GDP to our main measure of private credit to GDP. The estimates are almost identical to those reported in Table 3 ; this is likely due to the fact that the ratio of central bank credit to GDP is on average very low in the sample (sample mean of 0.04).

Next, given the importance of access to increasingly international capital markets, especially for some sectors, alternative measures of financial development that capture the international supply of capital beg to be considered. In the next two columns, we replace our proxy for financial depth with measures of stock and bond market capitalization to GDP. The results are consistent with the effect of credit markets on reallocation. Both deeper stock markets and deeper bond markets turn out to be associated with faster convergence toward the benchmark (Columns (2) and (3)), and the effect in both cases is significant at the $10 \%$ level. These findings are broadly in line with the growth effects in Rajan and Zingales (1998) and the volatility results in Braun and Larrain (2005), suggesting that there is nothing peculiar about credit market depth as a measure of financial development.

Next, we pay explicit attention to the fact that countries can also diversify abroad, both in terms of direct and portfolio investment, and this is likely to be especially important for small, 
open economies. While in our framework economies by construction cannot "short" a sector, we can still look at the effect of cross-border diversification. In Columns (4) we replace our measure of credit market development in (12) with a measure of trade openness (i.e., the ratio of exports plus imports to GDP). This measure of international integration has a significant effect on the sectors' speed of convergence to their MVE-implied optimal employment share. In Column (5) we replace our measure of credit market development with the ratio of gross and of net foreign assets and liabilities to GDP, both of which proxy for integration in international financial markets. We detect a significant association between the former and the speed of convergence toward an MVE-type industrial benchmark. The results thus suggest that domestic credit market deepening is not the sole force behind convergence toward a more optimally diversified industrial allocation, as trade integration and financial integration matter, too.

It is important to know if the effect of financial deepening is not dominated by the effect of concurrent developments. In Columns (6) and (7), we investigate whether the effect of financial development remains in place once the economy's integration in global markets is properly accounted for. The evidence suggests that the independent effect of financial deepening survives the inclusion of both measures of openness in the regression.

Finally, our data allow us to pay specific attention to financial services as a productive sector of the economy. In particular, some countries can have a comparative advantage in financial services due to specialization in a particular type of human capital, or due to early specialization in banking activities. A way to exploit this possibility is to test whether countries with initially relatively large financial sectors have diversification paths different from countries with initially relatively small financial sectors. We perform our main tests on these two subsamples of countries, and report the results in Columns (8) and (9). The estimates imply that deeper financial markets increase the speed of allocative efficiency for both types of countries; however, the gain in speed of convergence is relatively higher for countries that initially specialized to a higher degree in financial services (Column (9)).

In further robustness exercises, which can be found in the Appendix, we show that the effect of finance on convergence is robust to controlling for the effect of other characteristics of the business environment (Appendix Table A2), that it is stronger in countries that are less diversified initially (Appendix Table A3), and that it is robust to using an economic area rather than a country as 
the unit of observation (Appendix Table A4), and to including the 2008-2009 global recession in the sample period (Appendix Table A5). It is also robust to computing the underlying distances to benchmark industrial composition based on data on the growth of value added rather than on labor productivity growth (Appendix Table A6).

\section{Conclusion}

This paper investigates the effect of financial development on the economy's growth-volatility profile for a wide cross-section of countries. We document two main findings. First, financial development is Pareto-improving in the sense of delivering lower aggregate long-term volatility for the same level of long-term growth. Second, the reduction in aggregate volatility is realized through a reallocation of resources toward sectors whose growth profile is correlated with the rest of the economy in a way that gives them large optimal weights in an MVE sense. Thus, we identify a new channel through which financial development affects aggregate volatility, in addition to reducing the sectors' own long-term volatility. To the extent that output volatility and consumption volatility are correlated, our results suggest that financial development can have positive welfare implications through a reduction in overall economic volatility.

Crucially, our findings do not appear to be driven by a global shift away from volatile sectors during the Great Moderation, or by the endogeneity of financial development. In particular, our results survive panel regressions with a rich set of fixed effects, and they are not weakened when we use exogenous measures of financial development, such as banking deregulation. We also document that in financially developed countries, sectors converge faster to their optimal share in the industrial portfolio if they are naturally sensitive to external finance. At the same time, convergence is at play for both labor-intensive and capital-intensive sectors, weakening concerns that our results are driven by the fact that finance develops faster in economies dominated by capital-intensive industries.

How should one interpret the fact that financial deepening leads to faster convergence to a lowervolatility sectoral composition? In theory, one would expect the opposite to be true: as financial development allows for better risk sharing, the real economy can become more specialized, while the diversification demanded by the representative investor will come from financial assets. However, because of the MVE-based measure of diversification we employ throughout the paper, our results actually do not negate such a mechanism. In fact, we do show that financial deepening does not lead 
to convergence toward an optimal portfolio, calculated by setting the correlations across sectors to zero. We argue that finance encourages convergence toward a portfolio in which some sectors have large MVE-implied weights, whereas other sectors have small MVE-implied weights. To the extent that the large MVE-implied sectors can be those in which the economy is specializing, the mechanism we detect can be fully consistent with the risk-sharing function of financial deepening.

We stop short of a number of important extensions. For example, we do not explore whether our results will stand the test of dynamic measures of allocative efficiency, incorporating the idea of expanding technological frontiers a la Acemoglu et al. (2006). Also, due to data limitations, our sample also only consists of industrialized countries. Unlike standard cross-country cross-industry studies, which use data on manufacturing output for both developed and developing countries, our methodology requires output data for all sectors of the economy that are only consistently available for high-income countries. Using comparable data to investigate the effect of financial development on the overall growth-volatility profile in low-income economies could provide important insights into the economic costs - in terms of aggregate output volatility — of financial underdevelopment.

\section{References}

Acemoglu, D., Aghion, P., Zilibotti, F., 2006. Distance to frontier, selection, and economic growth. J. Eur. Econ. Assoc. 4, 37-74.

Acemoglu, D., Zilibotti, F., 1997. Was Prometheus unbound by chance? Risk, diversification, and growth. J. Polit. Econ. 105, 709-751.

Acharya, V., Imbs, J., Sturgess, J., 2011. Finance and efficiency: Do bank regulations matter? Rev. Finan. 15, 135-172.

Aghion, P., Banerjee, A., Piketty, T., 1999. Dualism and macroeconomic volatility. Q. J. Econ. $114,1359-1397$.

Aghion, P., Fally, T., Scarpetta, S., 2007. Credit constraints as a barrier to the entry and post-entry growth of firms. Econ. Policy 22, 731-779.

Arellano, M., Bond, S., 1991. Some tests of specification for panel data: Monte Carlo evidence and an application to employment equations. Rev. Econ. Stud. 58, 277-297.

Bachetta, P., Caminal, R., 2000. Do capital market imperfections exacerbate output fluctuations? Eur. Econ. Rev. 44, 449-468. 
Beck, T., Demirgüç-Kunt, A., Levine, R., 2013. Financial development and structure dataset. World Bank document.

Beck, T., Demirguc-Kunt, A., Levine, R., Maksimovic, V., 2001. Financial structure and economic development: Firm, industry, and country evidence. In Financial Structure and Economic Growth: A Cross-Country Comparison of Banks, Markets, and Development, eds., Asli DemirgucKunt and Ross Levine, Cambridge, MA: MIT Press.

Beck, T., Levine, R., Loayza, N., 2000. Finance and the sources of growth. J. Financ. Econ. 58, 261-300.

Beck, T., Lundberg, M., Majnoni, G., 2006. Financial intermediary development and growth volatility: Do intermediaries dampen or magnify shocks? J. Int. Money Financ. 25, 1146-1167.

Bekaert, G., Harvey, C., Lundblad, C., 2005. Does financial liberalization spur growth? J. Financ. Econ. 77, 3-55.

Bekaert, G., Harvey, C., Lundblad, C., 2006. Growth volatility and financial liberalization. J. Int. Money Financ. 25, 370-403.

Bekaert, G., Harvey, C., Lundblad, C., Siegel, S., 2007. Global growth opportunities and market integration. J. Financ. 62, 1081-1137.

Blundell, R., Bond, S.,1998. Initial conditions and model restrictions in dynamic panel data models. J. Econometrics 87, 115-143.

Bonfiglioli, A., 2008. Financial integration, productivity, and capital accumulation. J. Int. Econ. 76, 337-355.

Braun, M., Larrain, B., 2005. Finance and the business cycle: International, inter-industry evidence. J. Financ. 50, 1097-1128.

Caballero, R., Krishnamurty, A., 2001. International and domestic collateral constraints in a model of emerging market crises. J. Monetary Econ. 48, 513-548.

Caselli, F., 2005. Accounting for Cross-Country Income Differences. In The Handbook of Economic Growth, eds., Philippe Aghion and Steve Durlauf, Amsterdam, Netherlands: NorthHolland.

Cetorelli, N., Strahan, P., 2006. Finance as a barrier to entry: Bank competition and industry structure in local U.S. markets. J. Financ. 61, 437-461.

Easterly, W., Islam, R., Stiglitz, J., 2000. Shaken and stirred: Explaining growth volatility. In 
B. Pleskovic and J. E. Stiglitz, Annual Bank Conference on Development Economics, Washington D.C.

Fisman, R., Love, I., 2007. Financial dependence and growth revisited. J. Eur. Econ. Assoc. $5,470-479$.

Goldsmith, R., 1969. Financial Structure and Development. New Haven, CT: Yale University Press.

Gupta, N., Yuan, K., 2009. On the growth effect of stock market liberalizations. Review of Financial Studies 22, 4715-4752.

Hellmann, T., Murdock, K., Stiglitz, J., 2000. Liberalization, moral hazard in banking, and prudential regulation: Are capital requirements enough? Am. Econ. Rev. 90, 147-165.

Imbs, J., 2007. Growth and volatility. J. Monetary Econ. 54, 1848-1862.

Imbs, J., Wacziarg, R., 2003. Stages of diversification. Am. Econ. Rev. 93, 63-86.

Jagannathan, R., Ma, T., 2003. Risk reduction in large portfolios: Why imposing the wrong constraints helps? J. Financ. 55, 1651-1683.

Johnson, S., Larson, W., Papageorgiou, C., Subramanian, A., 2013. Is newer better? Penn World Table revisions and their impact on growth estimates. J. Monetary Econ. 60, 255-274.

Kaminsky, G., Reinhart, C., 1999. The twin crises: The causes of banking and balance-ofpayment problems. Am. Econ. Rev. 89, 473-500.

King, R., Levine, R., 1993a. Finance and growth: Schumpeter might be right. Q. J. Econ. 108, $717-737$.

King, R., Levine, R., 1993b. Finance, entrepreneurship, and growth: Theory and evidence. J. Monetary Econ. 32, 513-542.

Klapper, L., Laeven, L., Rajan, R., 2006. Entry regulation as a barrier to entrepreneurship. J. Financ. Econ. 82, 591-629.

Koren, M., Tenreyro, S., 2007. Volatility and development. Q. J. Econ. 122, 243-287.

Kose, M.A., Prasad, E., Terrones, M., 2006. How do trade and financial integration affect the relationship between growth and volatility? J. Int. Econ. 69, 176-202.

Lane, P., Milesi-Ferretti, G.M., 2007. The external wealth of nations mark II: Revised and extended estimates of foreign assets and liabilities, 1970-2004. J. Int. Econ. 73, 223-250.

Larrain, B., 2006. Do banks affect the level and composition of industrial volatility? J. Financ. 
$61,1897-1925$.

Larrain, B., 2010. Stock market development and cross-country differences in relative prices. Rev. Econ. Stat. 92, 784-797.

Levchenko, A., Ranciere, R., Thoenig, M., 2009. Growth and risk at the industry level: The real effects of financial liberalization. J. Dev. Econ. 89, 210-222.

Levine, R., 2005. Finance and Growth: Theory, Evidence, and Mechanisms. In The Handbook of Economic Growth, eds., Philippe Aghion and Steve Durlauf, Amsterdam, Netherlands: North-Holland.

Levine, R., Zervos, S., 1998. Stock markets, banks, and economic growth. Am. Econ. Rev. 88, $537-558$.

Markowitz, H., 1952. Portfolio selection. J. Financ. 7, 77-91.

McKinnon, R., 1973. Money and Capital in Economic Development. Washington, DC: Brookings Institution.

Morgan, D., Rime, B., Strahan, P., 2004. Bank integration and state business cycles. Q. J. Econ. 119, 1555-1584.

Palacios, M., 2011. Are labor-intensive assets riskier? Vandebilt University working paper.

Raddatz, C., 2006. Liquidity needs and vulnerability to financial underdevelopment. J. Financ. Econ. 80, 677-722.

Rajan, R., Zingales, L., 1998. Financial dependence and growth. Am. Econ. Rev. 88, 559-586.

Ramey, G., Ramey, V., 1995. Cross-country evidence on the link between volatility and growth. Am. Econ. Rev. 85, 1138-1151.

Schumpeter, J., 1991. The Theory of Economic Development. Cambridge, MA: Harvard University Press.

Wachtel, P., 2001. Growth and finance: What do we know and how do we know it? Int. Financ. 4, 335-362.

Wurgler, J., 2000. Financial markets and the allocation of capital. J. Financ. Econ. 58, 187-214. 
Table 1

Actual and MVE-implied employment shares, by industry.

\section{SIC 1-digit sector}

Sector 1. Agriculture, Hunting, Forestry, and Fishing

Sector 2. Mining and Quarrying

Sector 3. Manufacturing

Sector 4. Electricity, Gas, and Water Supply

Sector 5. Construction

Sector 6. Wholesale and Retail Trade and Restaurants and Hotels

Sector 7. Transport, Storage, and Communications

Sector 8. Finance, Insurance, Real Estate, and Business Services

Sector 9. Community, Social, and Personal Services

Note: This table summarizes actual and optimal employment shares as implied by the MVE criterion used in the paper, for nine SIC 1-digit industries. The underlying industry data on value added and employment are from the STAN Dataset for Industrial Analysis. The sample period is $1970--2007$. For the derivation of the optimal employment shares, see Section 2.2. See Appendix Table A7 for data sources.
MVE-implied optimal share 0.082

0.015

0.171

0.020

0.073

0.167

$\begin{array}{ll}0.063 & 0.099 \\ 0.112 & 0.031\end{array}$

$\begin{array}{ll}0.063 & 0.099 \\ 0.112 & 0.031\end{array}$

$\begin{array}{ll}0.112 & 0.031 \\ 0.269 & 0.342\end{array}$


Table 2

Difference between actual and MVE-implied employment shares.

\begin{tabular}{|c|c|c|c|c|c|c|c|c|c|}
\hline \multirow[b]{2}{*}{ Country } & \multicolumn{9}{|c|}{ Difference between actual and optimal employment shares, SIC 1-digit industries } \\
\hline & Sector 1 & Sector 2 & Sector 3 & Sector 4 & Sector 5 & Sector 6 & Sector 7 & Sector 8 & Sector 9 \\
\hline Australia & 0.046 & 0.011 & 0.080 & 0.015 & 0.027 & -0.618 & 0.070 & 0.115 & 0.252 \\
\hline Austria & 0.031 & -0.009 & -0.009 & 0.010 & -0.026 & 0.149 & -0.044 & 0.093 & -0.193 \\
\hline Belgium & 0.018 & 0.004 & 0.115 & 0.000 & 0.061 & -0.275 & 0.043 & 0.136 & -0.100 \\
\hline Canada & 0.043 & 0.010 & 0.166 & -0.010 & 0.015 & -0.092 & 0.012 & -0.013 & -0.140 \\
\hline Czech Republic & 0.048 & 0.013 & 0.158 & 0.013 & 0.071 & -0.013 & 0.070 & 0.107 & -0.468 \\
\hline Denmark & 0.056 & 0.000 & 0.108 & 0.009 & 0.066 & -0.043 & 0.028 & 0.107 & -0.327 \\
\hline Finland & 0.089 & 0.000 & 0.214 & 0.010 & 0.075 & -0.152 & 0.072 & 0.087 & -0.398 \\
\hline France & 0.034 & -0.280 & -0.161 & 0.010 & 0.014 & 0.072 & 0.059 & 0.136 & 0.127 \\
\hline Germany & 0.024 & 0.003 & 0.213 & 0.000 & 0.071 & -0.405 & 0.054 & 0.070 & -0.031 \\
\hline Greece & -0.231 & -0.030 & -0.093 & 0.010 & 0.004 & 0.135 & 0.064 & 0.076 & 0.068 \\
\hline Hungary & -0.049 & 0.005 & 0.229 & 0.001 & 0.062 & 0.131 & -0.136 & 0.041 & -0.276 \\
\hline Iceland & 0.078 & -0.120 & 0.150 & 0.010 & 0.023 & -0.129 & -0.004 & 0.110 & -0.113 \\
\hline Ireland & -0.077 & 0.003 & 0.096 & -0.010 & -0.330 & 0.027 & -0.072 & 0.110 & 0.254 \\
\hline Italy & -0.208 & 0.000 & 0.248 & -0.040 & 0.075 & 0.184 & 0.000 & 0.089 & -0.339 \\
\hline Japan & -0.864 & 0.000 & 0.218 & -0.020 & 0.095 & 0.225 & 0.060 & 0.101 & 0.178 \\
\hline Korea & -0.250 & 0.004 & 0.042 & -0.010 & 0.018 & 0.226 & 0.050 & 0.060 & -0.152 \\
\hline Luxembourg & -0.136 & 0.000 & 0.154 & -0.010 & 0.106 & -0.378 & -0.016 & 0.166 & 0.120 \\
\hline Netherlands & 0.024 & 0.000 & 0.115 & 0.007 & -0.022 & -0.019 & -0.120 & 0.153 & -0.139 \\
\hline New Zealand & 0.009 & 0.000 & -0.025 & 0.006 & 0.058 & 0.266 & -0.038 & 0.082 & -0.350 \\
\hline Norway & 0.064 & 0.012 & 0.159 & 0.010 & 0.065 & 0.179 & 0.053 & 0.090 & -0.631 \\
\hline Poland & -0.573 & 0.022 & 0.210 & 0.019 & -0.122 & 0.096 & 0.060 & 0.068 & 0.222 \\
\hline Portugal & 0.033 & -0.010 & -0.205 & 0.008 & 0.000 & 0.124 & 0.040 & 0.045 & -0.031 \\
\hline Slovakia & 0.055 & 0.007 & -0.047 & 0.020 & 0.030 & 0.171 & -0.038 & 0.049 & -0.240 \\
\hline Spain & 0.024 & 0.004 & 0.106 & 0.007 & -0.087 & 0.207 & -0.051 & 0.090 & -0.299 \\
\hline Sweden & 0.042 & 0.000 & 0.209 & 0.010 & 0.060 & 0.028 & 0.057 & 0.058 & -0.473 \\
\hline Switzerland & 0.043 & -0.020 & -0.034 & 0.010 & 0.073 & 0.221 & 0.053 & 0.085 & -0.430 \\
\hline UK & -0.020 & 0.007 & 0.060 & 0.007 & 0.070 & -0.603 & 0.060 & 0.148 & 0.277 \\
\hline U.S. & 0.023 & 0.006 & 0.156 & 0.006 & 0.035 & 0.220 & 0.051 & 0.151 & -0.646 \\
\hline Total & -0.056 & -0.014 & 0.098 & 0.002 & 0.026 & -0.014 & 0.020 & 0.096 & -0.159 \\
\hline
\end{tabular}

Note: This table summarizes the average difference between actual and optimal employment shares as implied by the MVE criterion used in the paper, for nine SIC 1-digit industries. The underlying industry data are from the STAN Dataset for Industrial Analysis. The sample period is 1970--2007. For the derivation of the optimal employment shares, see Section 2.2. Unlike in the empirical exercises throughout the paper, in this table the difference between actual and optimal employment share can be negative. A negative difference implies that the actual weight is lower than the optimal weight, and a positive difference implies the opposite. For the SIC 1-digit industrial classification used in the paper, see Table 1. See Appendix Table A7 for data sources. 
Table 3

Finance and convergence toward benchmark industrial composition.

\begin{tabular}{lll}
\hline & \multicolumn{1}{c}{$(1)$} & \multicolumn{1}{c}{$(2)$} \\
\cline { 2 - 3 } & \multicolumn{1}{c}{ OLS } & GMM \\
\hline$D_{c, s, t-1} \cdot$ Credit & $-0.0063^{* *}$ & $-0.0359^{* * *}$ \\
$D_{c, s, t-1}$ & $(0.0023)$ & $(0.0029)$ \\
& $0.9640^{* * *}$ & $0.9524^{* * *}$ \\
Credit & $(0.0071)$ & $(0.0038)$ \\
& 0.0002 & $0.0019^{* * *}$ \\
Observations & $(0.0004)$ & $(0.0005)$ \\
Country $\times$ industry dummies & 6,345 & 6,039 \\
Industry $\times$ year dummies & Yes & Yes \\
\hline
\end{tabular}

Note: This table reports estimates from fixed effects regressions, where the dependent variable is $D_{c, s, t}$, calculated according to Equation (12). The sample includes all countries for which the number of years with nonmissing data is at least as large as the number of industries. Estimates come from OLS regressions (Column (1)) and from a GMM procedure which implements the Arellano-Bond estimator to account for the presence of a lagged dependent variable in a dynamic panel model (Column (2)). "Credit" is the ratio of private credit to GDP. The sample period is 1970--2007. Standard errors clustered by industry appear below each coefficient in parentheses, where $* * *$ indicates significance at the $1 \%$ level, $* *$ at the $5 \%$ level, and $*$ at the $10 \%$ level. See Appendix Table A7 for data sources. 
Table 4

Stationarity and structural breaks issues.

\begin{tabular}{lll}
\hline & \multicolumn{1}{c}{$(1)$} & $(2)$ \\
\cline { 2 - 3 } & "Clean frontier" countries & Sample period splits \\
\hline$D_{c, s, t-1} \cdot$ Credit & $-0.0070^{* *}$ & $-0.0068^{*}$ \\
$D_{c, s, t-1}$ & $(0.0032)$ & $(0.0036)$ \\
& $0.9642^{* * *}$ & $1.0034^{* * *}$ \\
Credit & $(0.0104)$ & $(0.0052)$ \\
& -0.0003 & 0.0002 \\
Observations & $(0.0004)$ & $(0.0003)$ \\
Country $\times$ industry dummies & 4,257 & 6,075 \\
Industry $\times$ year dummies & Yes & Yes \\
\hline
\end{tabular}

Note: This table reports estimates from fixed effects regressions, where the dependent variable is $D_{c, s, t}$, calculated according to Equation (12). In Column (1), the sample includes all countries for which the number of years with nonmissing data is at least as large as the number of industries and that liberalized their credit markets before 1970. In Column (2), $D_{c, s, t}$ is estimated after splitting the data in two periods, 1970--1988 and 1989--2007, and estimating an MVE benchmark for each country, over two periods. "Credit" is the ratio of private credit to GDP. The sample period is 1970-2007. Standard errors clustered by industry appear below each coefficient in parentheses, where *** indicates significance at the $1 \%$ level, ** at the $5 \%$ level, and * at the $10 \%$ level. See Appendix Table A1 for credit market liberalization dates. See Appendix Table A7 for data sources. 
Table 5

Finance and convergence toward benchmark industrial composition: Which sectors converge faster?

\begin{tabular}{|c|c|c|c|c|}
\hline & (1) & (2) & (3) & (4) \\
\hline & \multicolumn{2}{|c|}{ External dependence } & \multicolumn{2}{|c|}{ Share young firms } \\
\hline & Low & High & Low & High \\
\hline \multirow{2}{*}{$D_{c, s, t-1} \cdot$ Credit } & -0.0078 & $-0.0060 * *$ & -0.0074 & $-0.0048 * *$ \\
\hline & $(0.0071)$ & $(0.0017)$ & $(0.0051)$ & $(0.0022)$ \\
\hline \multirow[t]{2}{*}{$D_{c, s, t-1}$} & $0.9706 * * *$ & $0.9561 * * *$ & $0.9661 * * *$ & $0.9552 * * *$ \\
\hline & $(0.0088)$ & $(0.0044)$ & $(0.0073)$ & $(0.0121)$ \\
\hline Credit & 0.0002 & 0.0003 & 0.0004 & 0.0001 \\
\hline Observations & 2,820 & 3,525 & 2,820 & 3,525 \\
\hline Country $\times$ industry dummies & Yes & Yes & Yes & Yes \\
\hline Industry $\times$ year dummies & Yes & Yes & Yes & Yes \\
\hline
\end{tabular}

Note: The dependent variable in all cases is $D_{c, s, t}$, calculated according to Equation (12). "Credit" is the ratio of private credit to GDP. "External dependence" is the sector's average median value of capital expenditures minus cash flows divided by capital expenditures over 1980--1990, for mature Compustat firms. "Share young firms" is the average share of firms younger than two years out of the full population of firms for U.S. industries over 1985--1995. The United States are excluded from the regressions. The sample period is 1970--2007. Standard errors clustered by industry appear below each coefficient in parentheses, where $* * *$ indicates significance at the $1 \%$ level, $* *$ at the $5 \%$ level, and * at the $10 \%$ level. See Appendix Table A7 for data sources. 
Table 6

Endogeneity of finance.

\begin{tabular}{lccc}
\hline & \multicolumn{1}{c}{$(1)$} & \multicolumn{1}{c}{$(2)$} & $(3)$ \\
\cline { 2 - 4 } & $\begin{array}{c}\text { Credit = Bank } \\
\text { liberalization date }\end{array}$ & $\begin{array}{c}\text { Financial sector } \\
\text { excluded }\end{array}$ & $\begin{array}{c}\text { Only labor-intensive } \\
\text { industries }\end{array}$ \\
\hline$D_{c, s, t-1} \cdot$ Credit & $-0.0061^{*}$ & $-0.0064^{* *}$ & $-0.0045^{* *}$ \\
$D_{c, s, t-1}$ & $(0.0037)$ & $(0.0026)$ & $(0.0021)$ \\
& $0.9633^{* * *}$ & $0.9633^{* * *}$ & $0.9666^{* * *}$ \\
Credit & $(0.0067)$ & $(0.0077)$ & $(0.0106)$ \\
& 0.0003 & 0.0003 & -0.0001 \\
Observations & $(0.003)$ & $(0.0005)$ & $(0.0005)$ \\
Country $\times$ industry dummies & 6,345 & 5,640 & 4,230 \\
Industry $\times$ year dummies & Yes & Yes & Yes \\
\hline
\end{tabular}

Note: The dependent variable in all cases is $D_{c, s, t}$, calculated according to Equation (12). "Credit" is the ratio of private credit to GDP. "Bank liberalization date" equals one for the years after the country liberalized its domestic credit market, and zero otherwise. The financial sector (SIC industry \#8) is excluded from the regression in Column (2). Labor-nonintensive sectors (i.e., sectors where labor compensation accounts for less than two-thirds of total production) are dropped from the regression in Column (3). The sample period is 1970--2007. Standard errors clustered by industry appear below each coefficient in parentheses, where $* * *$ indicates significance at the $1 \%$ level, ${ }^{* *}$ at the $5 \%$ level, and * at the $10 \%$ level. See Appendix Table A1 for credit market liberalization dates. See Appendix Table A7 for data sources. 
Table 7

Alternative measures of diversification.

\begin{tabular}{llcl}
\hline & \multicolumn{1}{c}{$(1)$} & \multicolumn{1}{c}{$(2)$} & \multicolumn{1}{c}{$(3)$} \\
\cline { 2 - 4 } & Corr $=0$ & Actual weight $-1 / \mathrm{N}$ & MVP \\
\hline$D_{c, t-1} \cdot$ Credit & -0.0050 & $-0.0150^{*}$ & -0.0024 \\
& $(0.0056)$ & $(0.0076)$ & $(0.0023)$ \\
Observations & 6,345 & 6,345 & 6,345 \\
Country $\times$ industry dummies & Yes & Yes & Yes \\
Industry $\times$ year dummies & Yes & Yes & Yes \\
\hline
\end{tabular}

Note: The dependent variable is $D_{c, s, t}$ in Column (1), calculated by setting correlations equal to zero in Equation (12), the absolute value of the difference between each sector's actual employment share and 1/N in Column (2), and $D_{c, s, t}$ in Column (3), calculated as the distance to the minimum variance portfolio in Equation (12). See Section 3.3 for details on how those are calculated. "Credit" is the ratio of private credit to GDP. The sample period is 1970--2007. Standard errors clustered by industry appear below each coefficient in parentheses, where $* * *$ indicates significance at the $1 \%$ level, $* *$ at the $5 \%$ level, and $*$ at the $10 \%$ level. See Appendix Table A7 for data sources. 
Table 8

Alternative measures of finance.

\begin{tabular}{|c|c|c|c|c|c|c|c|c|c|}
\hline & $(1)$ & $(2)$ & (3) & (4) & $(5)$ & (6) & (7) & $(8)$ & (9) \\
\hline$D_{c, s, t-1} \cdot$ Credit & & & & & & $\begin{array}{l}-0.0035^{*} \\
(0.0021)\end{array}$ & $\begin{array}{l}-0.0033^{*} \\
(0.0019)\end{array}$ & $\begin{array}{l}-0.0095 \\
(0.0092)\end{array}$ & $\begin{array}{l}-0.0043^{*} \\
(0.0022)\end{array}$ \\
\hline$D_{c, s, t-1} \cdot$ Credit (including CB) & $\begin{array}{l}-0.0069 * * \\
(0.0027)\end{array}$ & & & & & & & & \\
\hline$D_{c, s, t-1} \cdot$ Stock & & $\begin{array}{l}-0.0031^{*} \\
(0.0016)\end{array}$ & & & & & & & \\
\hline$D_{c, s, t-1} \cdot$ Bonds & & & $\begin{array}{l}-0.0062 * \\
(0.0036)\end{array}$ & & & & & & \\
\hline$D_{c, s, t-1} \cdot$ Trade & & & & $\begin{array}{l}-0.0009 * \\
(0.0005)\end{array}$ & & $\begin{array}{l}-0.0007^{*} \\
(0.0004)\end{array}$ & & & \\
\hline$D_{c, s, t-1} \cdot$ Gross foreign assets & & & & & $\begin{array}{l}-0.0007^{* *} \\
0.0003)\end{array}$ & & $\begin{array}{l}-0.0007^{*} \\
(0.0003)\end{array}$ & & \\
\hline$D_{c, s, t-1} \cdot$ Net foreign assets & & & & & $\begin{array}{l}0.0012 \\
(0.0035)\end{array}$ & & $\begin{array}{l}-0.0032 \\
(0.0034)\end{array}$ & & \\
\hline Observations & 6,120 & 6,624 & 6,084 & 6,525 & 6,408 & 6,246 & 6,165 & 2,981 & 2,968 \\
\hline Country $\times$ industry dummies & Yes & Yes & Yes & Yes & Yes & Yes & Yes & Yes & Yes \\
\hline Industry $\times$ year dummies & Yes & Yes & Yes & Yes & Yes & Yes & Yes & Yes & Yes \\
\hline
\end{tabular}

Note: The dependent variable is $D_{c, s, t}$, calculated according to Equation (12). "Credit" is the ratio of private credit to GDP. "Credit (private and CB)" is the

ratio of the sum of private credit and central bank assets to GDP. "Stock" is the ratio of stock market capitalization to GDP. "Bonds" is the ratio of private plus public bonds to GDP. "Trade" is the ratio of exports plus imports to GDP. "Gross foreign assets" is the ratio of foreign assets plus liabilities to GDP. "Net foreign assets" is the ratio of foreign assets to GDP. In Column (8), the analysis is performed on the countries that fall in the bottom half of the distribution of financial sector share of total value added in the initial year of data availability. In Column (9), the analysis is performed on the countries that fall in the top half of the distribution of financial sector share of total value added in the initial year of data. The sample period is 1970--2007. Standard errors clustered by industry appear below each coefficient in parentheses, where *** indicates significance at the $1 \%$ level, $* *$ at the $5 \%$ level, and $*$ at the $10 \%$ level. See Appendix Table A7 for data sources. 
Figure 1. Benchmark versus actual industrial composition over time, United States.

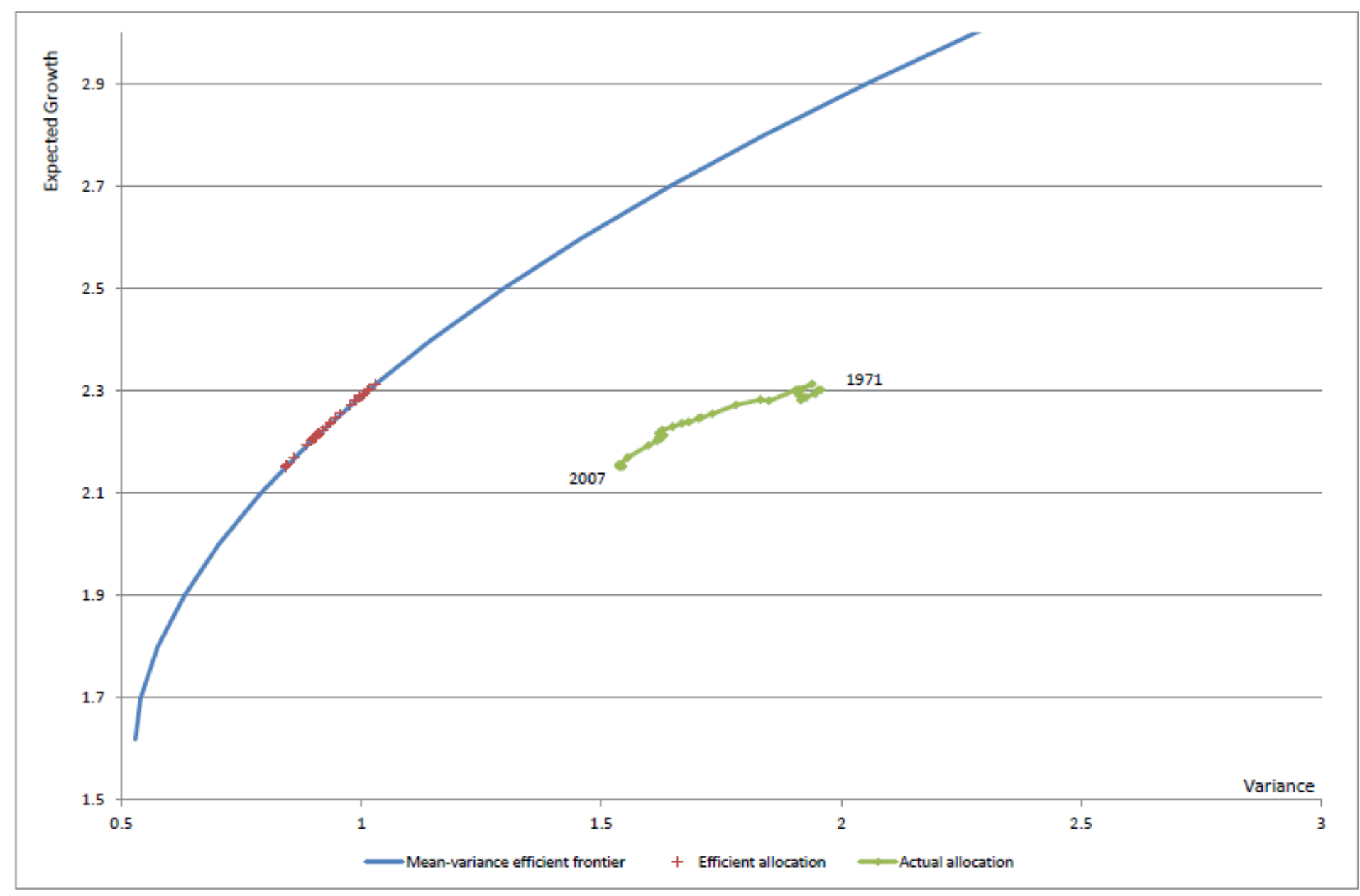

Note: The graph shows the benchmark allocation of employment across sectors, based on mean-variance efficiency and calculated using the sectors' long-term labor productivity growth, volatility, and correlations over the sample period, and the actual realization of sectoral employment, for the United States. The sample period is 1971--2007. 
Figure 2. Benchmark versus actual industrial composition over time, euro area.

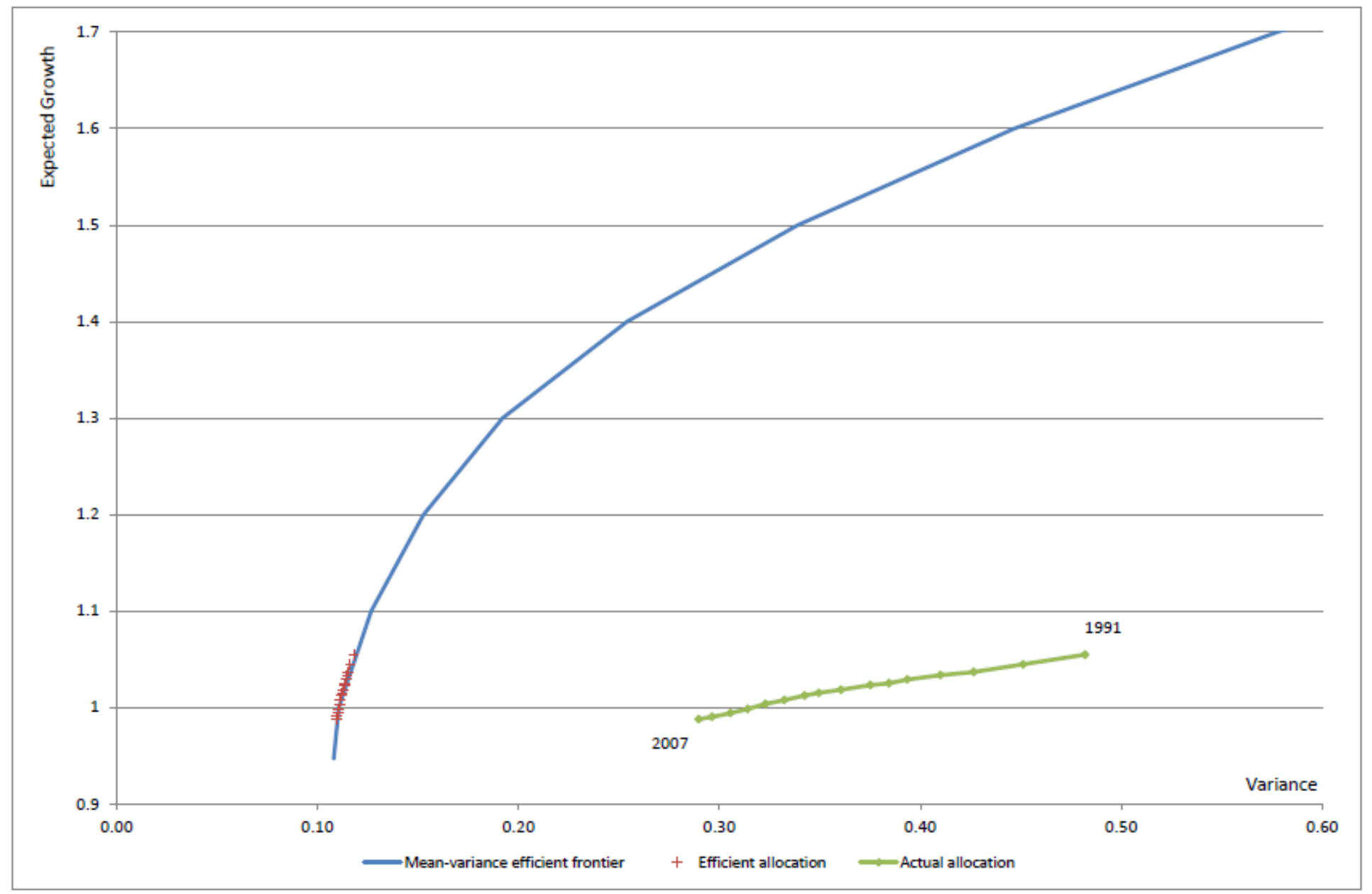

Note: The graph shows the benchmark allocation of employment across sectors, based on mean-variance efficiency and calculated using the sectors' long-term labor productivity growth, volatility, and correlations over the sample period, and the actual realization of sectoral employment, for the euro area. The sample period is 1991--2007. 
Figure 3. Benchmark versus actual industrial composition over time, Japan.

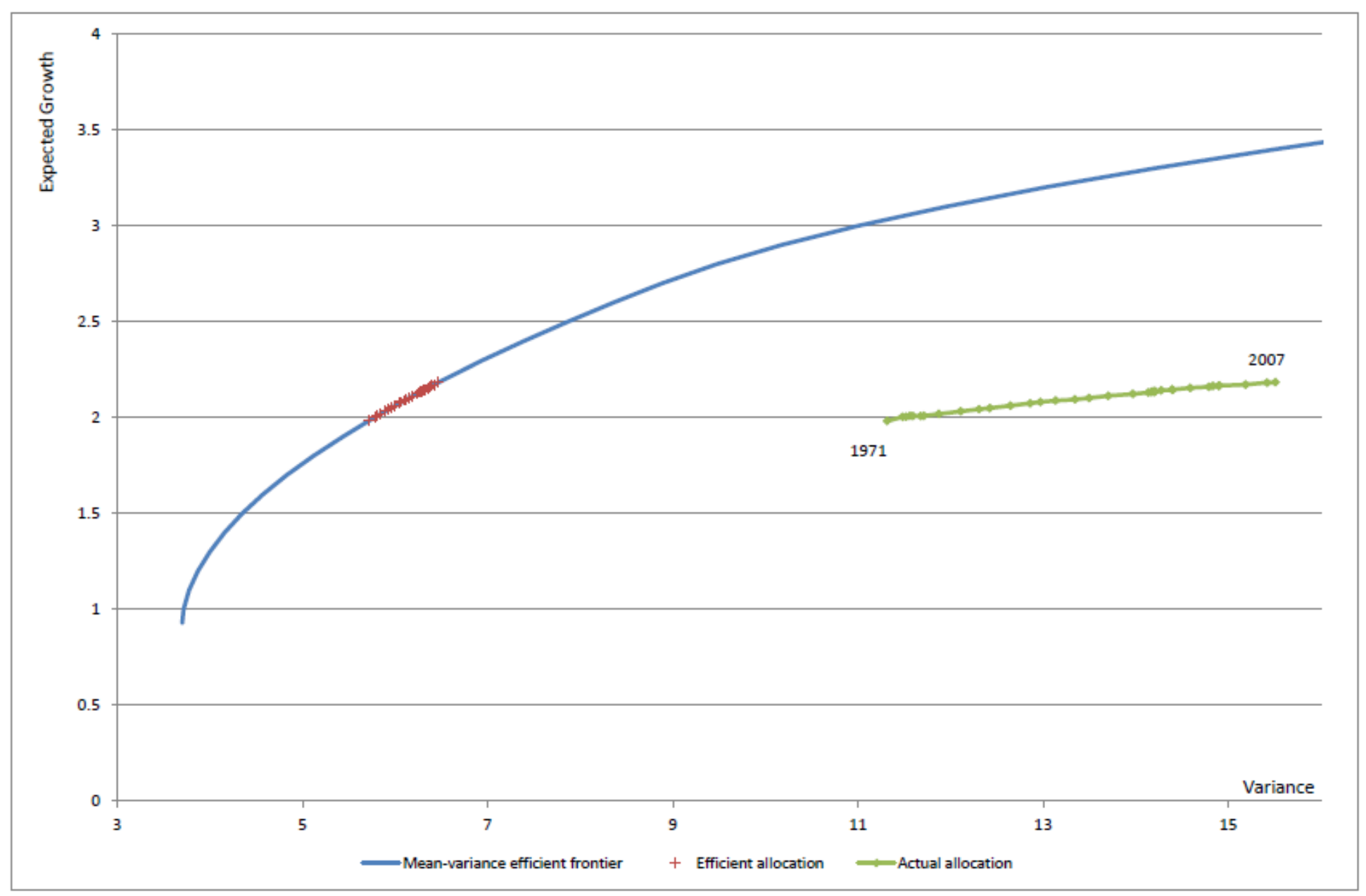

Note: The graph shows the benchmark allocation of employment across sectors, based on mean-variance efficiency and calculated using the sectors' long-term labor productivity growth, volatility, and correlations over the sample period, and the actual realization of sectoral employment, for Japan. The sample period is 1971--2007. 
Figure 4. Speed of convergence toward benchmark industrial composition and initial private credit/GDP.

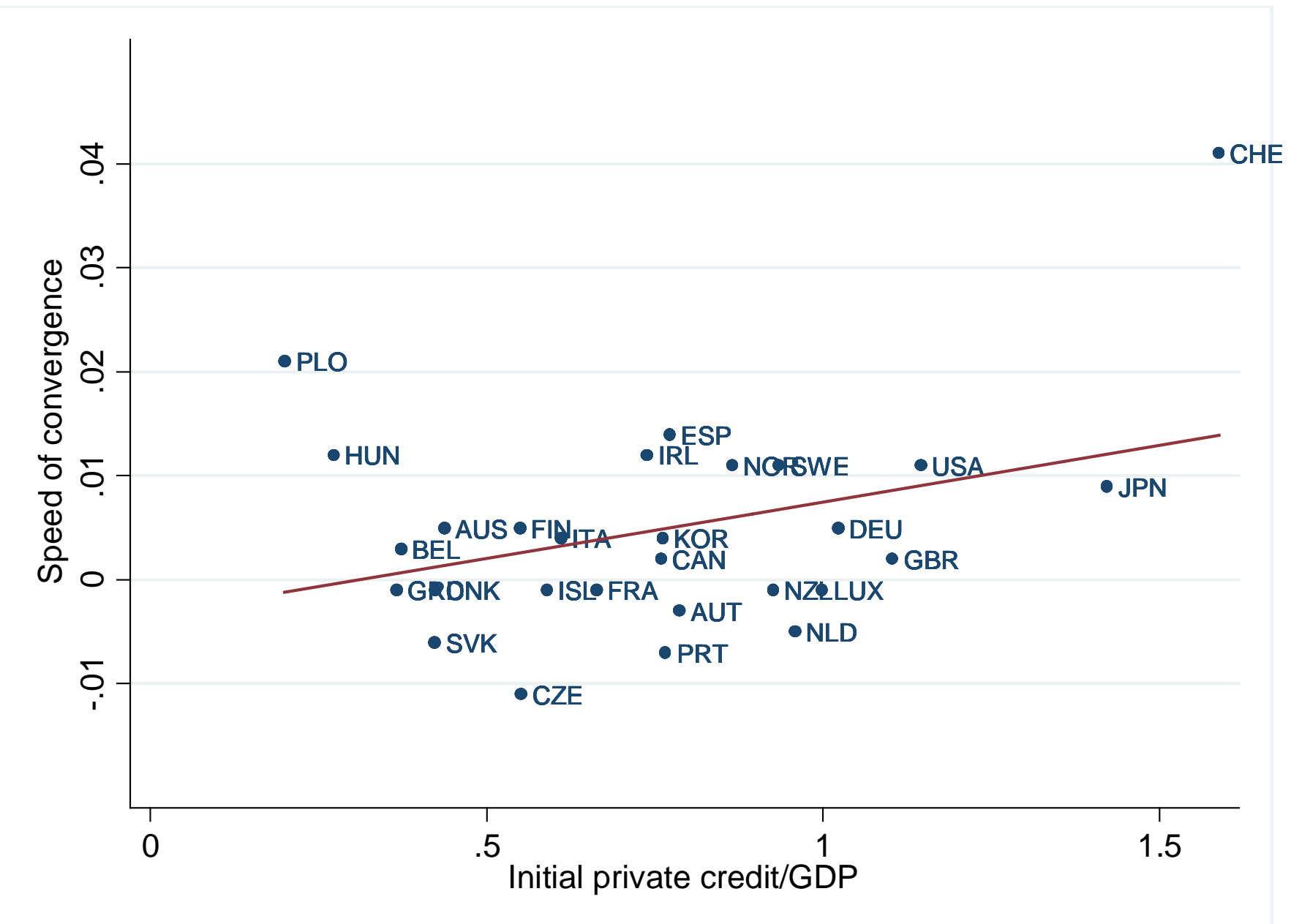

Note: The graph shows each individual country's autoregressive annual speed of convergence for the 1970--2007 sample period to the benchmark industrial allocation against beginning-of-sample period private credit to GDP. See Section 2 for details on the derivation of the benchmark industrial allocation. 
Figure 5. Final distance toward benchmark industrial composition and initial private credit/GDP.

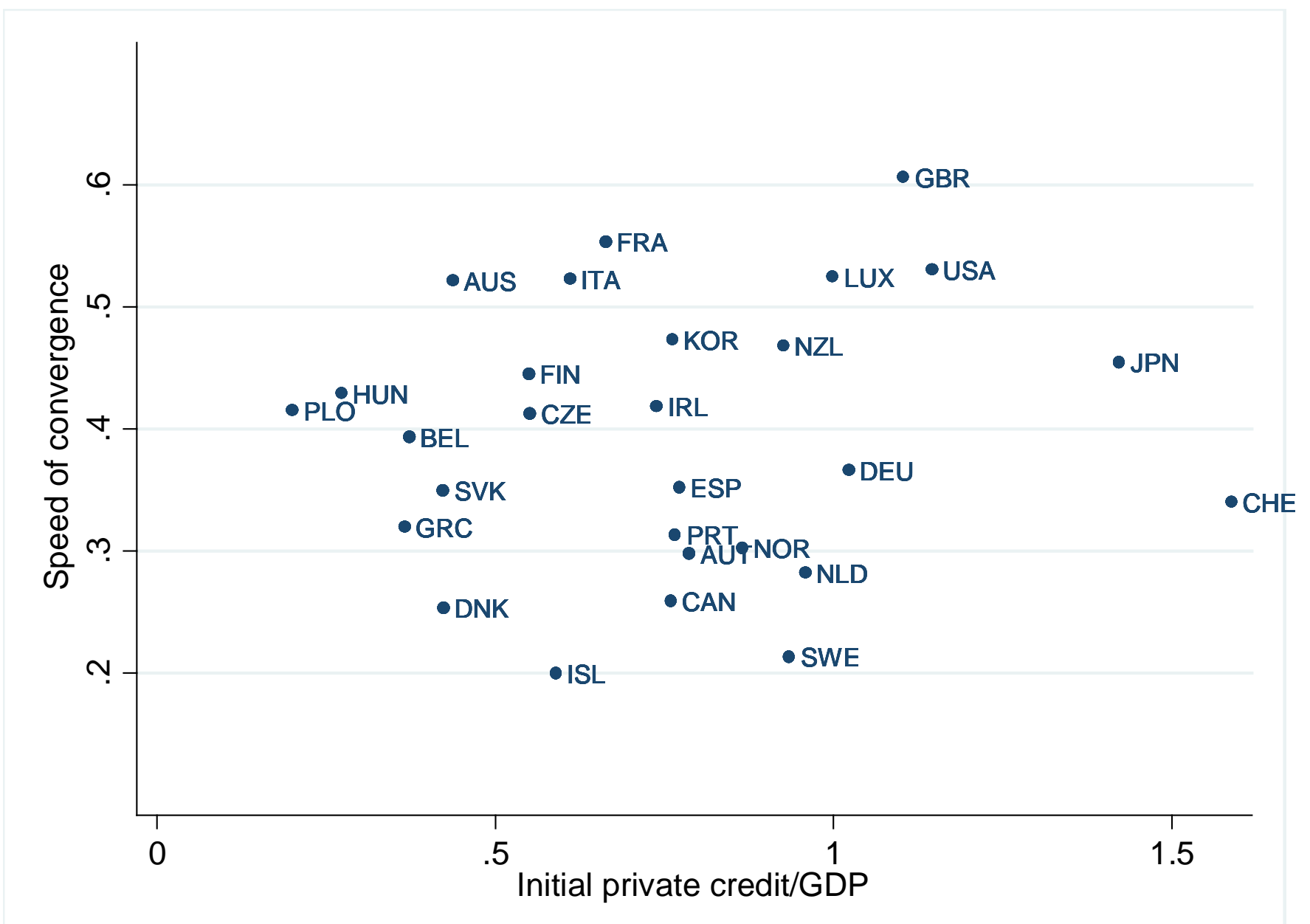

Note: The graph shows each individual country's final distance to MVE frontier for the 1970--2007 sample period against beginning-of-sample period private credit to GDP. See Section 2 for details on the derivation of the benchmark industrial allocation. 
Appendix Table A1

Credit markets: Private credit / GDP and banking sector liberalization events.

\begin{tabular}{lcc}
\hline & \multicolumn{2}{c}{ Credit markets } \\
\cline { 2 - 3 } & Private credit / GDP & Liberalization date \\
\hline Australia & 0.513 & 1994 \\
Austria & 0.841 & $<1970$ \\
Belgium & 0.433 & $<1970$ \\
Canada & 0.783 & $<1970$ \\
Czech Republic & 0.507 & 1994 \\
Denmark & 0.501 & 1994 \\
Finland & 0.571 & $<1970$ \\
France & 0.713 & $<1970$ \\
Germany & 1.077 & $<1970$ \\
Greece & 0.371 & 1987 \\
Hungary & 0.299 & 1994 \\
Iceland & 0.541 & $<1970$ \\
Ireland & 0.821 & $<1970$ \\
Italy & 0.618 & $<1970$ \\
Japan & 1.452 & 1985 \\
Korea & 0.827 & 1998 \\
Luxembourg & 1.054 & $<1970$ \\
Netherlands & 1.069 & $<1970$ \\
New Zealand & 0.558 & 1987 \\
Norway & 0.869 & 1985 \\
Poland & 0.236 & 1994 \\
Portugal & 0.856 & 1986 \\
Slovakia & 0.504 & 1994 \\
Spain & 0.811 & $<1970$ \\
Sweden & 0.956 & 1985 \\
Switzerland & 1.601 & $<1970$ \\
UK & 0.653 & 1970 \\
U.S. & 1.306 & 1985 \\
\hline Note: This & & $C 01040$ \\
\end{tabular}

Note: This table describes the main financial variable used in the text, private credit over GDP. Column (1) lists the country-level ratio of private credit by all financial institutions, excluding central banks, to GDP, averaged over the sample period. Column (2) lists the year in which the respective country liberalized its banking sector; "<1970" means that those countries' credit markets are open throughout the period. The sample period is 1970--2007. See Appendix Table A7 for data sources. 
Appendix Table A2

Finance, law, and institutions.

\begin{tabular}{ll}
\hline & \multicolumn{1}{c}{$(1)$} \\
\hline$D_{c, s, t-1} \cdot$ Credit & $-0.0060^{* *}$ \\
$D_{c, s, t-1} \cdot$ Entry time & $(0.0024)$ \\
$D_{c, s, t-1} \cdot$ Investor protection & -0.0001 \\
& $(0.0004)$ \\
$D_{c, s, t-1} \cdot$ Contract enforcement & -0.0005 \\
& $(0.0031)$ \\
$D_{c, s, t-1}$ & 0.0001 \\
Observations & $(0.0001)$ \\
Country $\times$ industry dummies & $0.9631^{* * *}$ \\
Industry $\times$ year dummies & $(0.0193)$ \\
\hline
\end{tabular}

Note: The dependent variable is $D_{c, s, t}$, calculated according to Equation (12). "Credit" is the ratio of private credit to GDP. "Entry time" is the number of days necessary to start a business in the respective country. "Investor protection" is an average of three indices of degree of protecting private investors. "Contract enforcement" is the number of days necessary to settle a contractual dispute in court. The sample period is 1970--2007. Standard errors clustered by country-industry appear below each coefficient in parentheses, where *** indicates significance at the $1 \%$ level, ** at the $5 \%$ level, and * at the $10 \%$ level. See Appendix Table A7 for data sources. 
Appendix Table A3

Finance and stages of diversification.

\begin{tabular}{lcc}
\hline & $(1)$ & $(2)$ \\
\cline { 2 - 3 } & Low initial diversification & High initial diversification \\
\hline$D_{c, s, t-1} \cdot$ Credit & $-0.0142^{*}$ & -0.0020 \\
& $(0.0082)$ & $(0.0051)$ \\
$D_{c, s, t-1}$ & $0.9732 * * *$ & $0.9586^{* * *}$ \\
& $(0.0076)$ & $(0.0128)$ \\
Credit & 0.0004 & 0.0001 \\
& $(0.0007)$ & $(0.0008)$ \\
Observations & 3,256 & 3,089 \\
Country $\times$ industry dummies & Yes & Yes \\
Industry $\times$ year dummies & Yes & Yes \\
\hline
\end{tabular}

Note: The dependent variables is $D_{c, s, t}$, calculated according to Equation (12). "Credit" is the ratio of private credit to GDP. "Low initial diversification" refers to the countries which are in the bottom half of the allocativeefficiency implied diversification distribution in the first year of data availability. "High initial diversification" refers to the countries which are in the top half of the allocative-efficiency implied diversification distribution in the first year of data availability. The sample period is 1970--2007. Standard errors clustered by countryindustry appear below each coefficient in parentheses, where *** indicates significance at the $1 \%$ level, ${ }^{* *}$ at the $5 \%$ level, and * at the $10 \%$ level. See Appendix Table A7 for data sources. 
Appendix Table A4

Finance and convergence toward benchmark industrial composition in larger economic zones.

\begin{tabular}{lllll}
\hline & $(1)$ & $(2)$ & \multicolumn{1}{c}{$(3)$} & $(4)$ \\
\cline { 2 - 5 } & \multicolumn{1}{c}{ OLS } & Arellano - Bond & $\begin{array}{c}\text { Financial sector } \\
\text { excluded }\end{array}$ & 2SLS \\
\hline$D_{c, s, t-1} \cdot$ Credit & $-0.0201^{*}$ & -0.0161 & $-0.0362^{* *}$ & -0.0215 \\
$D_{c, s, t-1}$ & $(0.0106)$ & $(0.0157)$ & $(0.0172)$ & $(0.0212)$ \\
& $0.9648^{* * *}$ & $0.9234^{* * *}$ & $0.9290^{* * *}$ & $0.9658^{* * *}$ \\
Observations & $(0.0207)$ & $(0.0181)$ & $(0.0465)$ & $(0.0252)$ \\
Industry dummies & 135 & 126 & 120 & 135 \\
Year dummies & Yes & Yes & Yes & Yes \\
\hline
\end{tabular}

Note: The dependent variable is $D_{c, s, t}$, calculated according to Equation (12), using aggregated data for the 12

original euro zone countries, at the SIC 1-digit level of disaggregation. "Credit" is the ratio of private credit to GDP for the 12 original euro zone countries. Column (1) reports OLS regression estimates. Column (2) reports the estimates from a GMM procedure that implements the Arellano-Bond estimator to account for the presence of a lagged dependent variable in a dynamic panel model. The financial sector (SIC industry \#8) is excluded from the regression in Column (5). In Column (4), the credit variable has been instrumented using an indicator variable equal to 1 after 1999 (the year of the introduction of the euro). The sample period is 1991--2007. Standard errors clustered by industry appear below each coefficient in parentheses, where $* * *$ indicates significance at the $1 \%$ level, $* *$ at the $5 \%$ level, and $*$ at the $10 \%$ level. See Appendix Table A7 for data sources. 
Appendix Table A5

Finance and convergence toward benchmark industrial composition: The impact of the 2008--2009 crisis.

\begin{tabular}{lll}
\hline & \multicolumn{1}{c}{$(1)$} & \multicolumn{1}{c}{$(2)$} \\
\cline { 2 - 3 }$D_{c, s, t-1} \cdot$ Credit & OLS & GMM \\
$D_{c, s, t-1}$ & $-0.0040^{* *}$ & $-0.0794^{* * *}$ \\
& $(0.0017)$ & $(0.0060)$ \\
Credit & $0.9499^{* * *}$ & $0.9576^{* * *}$ \\
& $(0.0092)$ & $(0.0078)$ \\
Observations & 0.0002 & $0.0053^{* * *}$ \\
Country $\times$ industry dummies & $(0.0004)$ & $(0.0008)$ \\
Industry $\times$ year dummies & 6,543 & 6,237 \\
\hline
\end{tabular}

Note: This table reports estimates from fixed effects regressions where the dependent variable is $D_{c, s, t}$,

calculated according to Equation (12). The regressions are carried out on the sample of all countries for which the number of years with nonmissing data is at least as large as the number of industries. "Credit" is the ratio of private credit to GDP. Estimates are from OLS regressions (column labelled "OLS") and from a GMM procedure that implements the Arellano-Bond estimator to account for the presence of a lagged dependent variable in a dynamic panel model (column labelled "GMM"). The sample period is 1970--2009. Standard errors clustered by country-industry appear below each coefficient in parentheses, where $* * *$ indicates significance at the $1 \%$ level, ${ }^{* *}$ at the $5 \%$ level, and $*$ at the $10 \%$ level. See Appendix Table A7 for data sources. 
Appendix Table A6

Finance and convergence toward benchmark industrial composition: Using value-added growth data to compute the industry benchmark.

\begin{tabular}{|c|c|c|c|c|}
\hline & (1) & (2) & (3) & (4) \\
\hline & \multicolumn{2}{|c|}{ All countries } & \multicolumn{2}{|c|}{ Clean frontier } \\
\hline & OLS & GMM & OLS & GMM \\
\hline$D_{c, s, t-1} \cdot$ Credit & $\begin{array}{l}-0.0326^{* * *} \\
(0.0092)\end{array}$ & $\begin{array}{l}-0.1382^{* * *} \\
(0.0078)\end{array}$ & $\begin{array}{l}-0.0590^{* * *} \\
(0.0208)\end{array}$ & $\begin{array}{l}-0.1688^{* * *} \\
(0.0134)\end{array}$ \\
\hline$D_{c, s, t-1}$ & $\begin{array}{l}0.9270 * * * \\
(0.0449)\end{array}$ & $\begin{array}{l}0.8377 * * * \\
(0.0174)\end{array}$ & $\begin{array}{l}0.9398 * * * \\
(0.0576)\end{array}$ & $\begin{array}{l}0.8796^{* * *} \\
(0.0154)\end{array}$ \\
\hline Credit & $\begin{array}{l}0.0018 * * \\
(0.0009)\end{array}$ & $\begin{array}{l}0.0043^{* *} \\
(0.0018)\end{array}$ & $\begin{array}{l}0.0024 \\
(0.0015)\end{array}$ & $\begin{array}{l}-0.0011 \\
(0.0030)\end{array}$ \\
\hline Observations & 6,633 & 6,498 & 4,059 & 3,731 \\
\hline Country $\times$ industry dummies & Yes & Yes & Yes & Yes \\
\hline Industry $\times$ year dummies & Yes & Yes & Yes & Yes \\
\hline
\end{tabular}

Note: This table reports estimates from fixed effects regressions, where the dependent variable is $D_{c, s, t}$. It is calculated according to Equation (12), where we use data on growth in value added, rather than on growth in value added per worker. The regressions are carried out on the sample of all countries for which the number of years with nonmissing data is at least as large as the number of industries (Columns (1) and (2)), and on the subsample of countries that liberalized their credit markets before the sample period (Columns (3) and (4)). "Credit" is the ratio of private credit to GDP. All estimates are from OLS regressions (columns labelled "OLS") and from a GMM procedure which implements the Arellano-Bond estimator to account for the presence of a lagged dependent variable in a dynamic panel model (columns labelled "GMM"). The sample period is 1970-2007. Standard errors clustered by country-industry appear below each coefficient in parentheses, where *** indicates significance at the $1 \%$ level, $* *$ at the $5 \%$ level, and * at the $10 \%$ level. See Appendix Table A7 for data sources. 
Appendix Table A7

Variables and sources.

Value added

Total sectoral value added, per country. Available for 9 SIC 1-digit industries for 28 OECD countries, at best staring in 1970. Constructed by deflating nominal growth rates. Source: STAN Database for Structural Analysis.

Employment

Total sectoral employment, per country. Available for 9 SIC 1-digit industries for 28 OECD countries, at best staring in 1970. Source: STAN Database for Structural Analysis.

External dependence

The sector's median value of capital expenditures minus cash flows divided by capital expenditures for 1980--1990, for mature Compustat firms. Source: Compustat.

Share young firms

Share of firms younger than 2 years out of the total population of firms, for U.S. corporations. Calculated for 1-digit SIC industries. Average for the years 1985-95. Source: Dun \& Bradstreet.

Labor intensity

The median ratio of total compensation to industrial production in the United States over 1947--1997. Source: Palacios (2011).

Credit

The value of total credits by financial intermediaries to the private sector in each country, available with annual frequency. Excludes credit by central banks. Calculated using the following deflation method: $\left\{(0.5) *\left[\mathrm{Ft} / \mathrm{P} \_\right.\right.$et $+\mathrm{Ft}-1 / \mathrm{P} \_$et$1]\} /\left[G D P \_t / P \_a t\right]$ where $\mathrm{F}$ is credit to the private sector, $\mathrm{P} \_\mathrm{e}$ is end-of period CPI, and $\bar{P}_{-} \mathrm{a}$ is average annual CPI. Source: Beck et al. (2013).

Credit (including CB) The value of total credits by financial intermediaries to the private sector in each country, available with annual frequency, including credit by central banks. Calculated using the following deflation method: $\left\{(0.5) *\left[\mathrm{Ft} / \mathrm{P} \_\right.\right.$et + Ft-1/P_et$1]\} /\left[G D P \_t / P \_a t\right]$ where $F$ is credit to the private sector, $P \_$e is end-of period CPI, and P_a is average annual CPI. Source: Beck et al. (2013).

Stock

Value of listed shares to GDP, calculated using the following deflation method: $\left\{(0.5) *\left[\mathrm{Ft} / \mathrm{P} \_\right.\right.$et + Ft-1/P_et-1] $\} /\left[\mathrm{GDPt} / \mathrm{P} \_\right.$at $]$where $\mathrm{F}$ is stock market capitalization, $\mathrm{P} \_$e is end-of period CPI, and $\mathrm{P} \_\mathrm{a}$ is average annual CPI. Source: Beck et al. (2013).

Bonds

Private domestic debt securities issued by financial institutions and corporations plus public domestic debt securities issued by government as a share of GDP, calculated using the following deflation method: $\left\{(0.5) *\left[\mathrm{Ft} / \mathrm{P} \_\right.\right.$et + Ft-1/P_et$1]\} /\left[\mathrm{GDPt} / \mathrm{P} \_\right.$at] where $\mathrm{F}$ is amount outstanding of private plus public domestic debt securities, $\mathrm{P} \_$e is end-of period CPI, and $\mathrm{P}_{-} \mathrm{a}$ is average annual CPI. Source: Beck et al. (2013).

Trade

The sum of exports and imports of the total economy over GDP. Available for 28 OECD countries, at best staring in 1970, with annual frequency. Source: Penn World Tables.

Gross foreign assets

The sum of total foreign assets and liabilities over GDP, with annual frequency. Source: Lane and Milesi-Ferretti (2007).

Net foreign assets

Total foreign assets over GDP, with annual frequency. Source: Lane and MilesiFerretti (2007). 
Bank liberalization

Entry time

Investor protection

Contract enforcement
Dummy variable equal to 1 after the year in which domestic credit markets were open to foreign participation. Source: Bekaert et al. (2005).

The time (in days) it takes to register a new business entity in the respective country. Data aggregated over the time period. Source: Doing Business Database.

Average of three indices of protection of investors: transparency of transactions, liability for self-dealing, and shareholders' ability to sue officers and directors for misconduct. Data aggregated over the time period. Source: Doing Business Database.

Number of days it takes to resolve a contractual dispute in the respective country. Data aggregated over the time period. Source: Doing Business Database. 